\title{
Article \\ Hydrodynamics and Mass Transfer in a Concentric Internal Jet-Loop Airlift Bioreactor Equipped with a Deflector
}

\author{
Radek Šulc*(1) and Jan Dymák \\ Department of Process Engineering, Faculty of Mechanical Engineering, Czech Technical University in Prague, \\ Technická 4, 16000 Prague, Czech Republic; JanDymak@seznam.cz \\ * Correspondence: Radek.Sulc@fs.cvut.cz; Tel.: +420-2-2435-2558
}

Citation: Šulc, R.; Dymák, J.

Hydrodynamics and Mass Transfer in a Concentric Internal Jet-Loop Airlift Bioreactor Equipped with a Deflector. Energies 2021, 14, 4329. https:// doi.org/10.3390/en14144329

Academic Editors: Dmitry Eskin and Štěpán Papáček

Received: 31 May 2021

Accepted: 12 July 2021

Published: 18 July 2021

Publisher's Note: MDPI stays neutral with regard to jurisdictional claims in published maps and institutional affiliations.

Copyright: (c) 2021 by the authors. Licensee MDPI, Basel, Switzerland. This article is an open access article distributed under the terms and conditions of the Creative Commons Attribution (CC BY) license (https:/ / creativecommons.org/licenses/by/ $4.0 /)$.

\begin{abstract}
The gas-liquid hydrodynamics and mass transfer were studied in a concentric tube internal jet-loop airlift reactor with a conical bottom. Comparing with a standard design, the gas separator was equipped with an adjustable deflector placed above the riser. The effect of riser superficial gas velocity $u_{S G R}$ on the total gas holdup $\varepsilon_{G T}$, homogenization time $t_{H}$, and overall volumetric liquid-phase mass transfer coefficient $k_{L} a$ was investigated in a laboratory bioreactor, of $300 \mathrm{~mm}$ in inner diameter, in a two-phase air-water system and three-phase air-water-PVC-particle system with the volumetric solid fraction of $1 \%$ for various deflector clearances. The airlift was operated in the range of riser superficial gas velocity from 0.011 to $0.045 \mathrm{~m} / \mathrm{s}$. For the gas-liquid system, when reducing the deflector clearance, the total gas holdup decreased, the homogenization time increased twice compared to the highest deflector clearance tested, and the overall volumetric mass transfer coefficient slightly increased by $10-17 \%$. The presence of a solid phase shortened the homogenization time, especially for lower $u_{S G R}$ and deflector clearance, and reduced the mass transfer coefficient by 15-35\%. Compared to the gas-liquid system, the noticeable effect of deflector clearance was found for the $k_{L} a$ coefficient, which was found approx. $20-29 \%$ higher for the lowest tested deflector clearance.
\end{abstract}

Keywords: conical draft tube airlift reactor; gas holdup; homogenization time; mass transfer

\section{Introduction}

\subsection{Algae Potential}

Algae represent a wide group of aquatic photosynthetic organisms ranging from a single cell to multicellular structures. Two main groups called microalgae and macroalgae; therefore, are distinguished. The details regarding the bioactive compounds produced by macroalgae are presented by Lafarga et al. [1], and cultivation systems are discussed by Papacek et al. [2].

The microalgae produce lipids, polysaccharides, pigments (carotenoids), vitamins, and other biologically active substances having antioxidant, antibacterial, antitumor, antihypertensive, neuroprotective, anti-inflammatory, and immunostimulating effects [3]. Carotenoids such as $\beta$-carotene [4], astaxanthin [5], and lutein [6] are produced by microalgae. On the health market, the natural $\beta$-carotene produced by microalgae is valued more than that synthetically produced. Guedes et al. [4] reported that the price of microalgae $\beta$-carotene produced in the year 2011 reached $700 € / \mathrm{kg}$, more than twice compared with synthetically produced substances.

To produce $1 \mathrm{~kg}$ of biomass, the microalgae consumes 1.8 to $2 \mathrm{~kg}$ of $\mathrm{CO}_{2}$ [3]. Therefore, microalgae is a highly efficient system for $\mathrm{CO}_{2}$ fixation compared with agricultural crops or forests, due to much higher growth rates and a very short harvesting cycle [7]. The potential of microalgal $\mathrm{CO}_{2}$ sequestration was discussed for fuel gases generated by the power industry [8] or car vehicles [9]. Thanks to the high content of lipids and polysaccharides and high biomass yield connected with fast growth, microalgae have been considered as the third generation feedstock for biodiesel and bioethanol production [10]. 
The microalgae potential for biodiesel production was investigated in an airlift reactor and bubble column [11], or integrated with a wastewater treatment system [12]. The effect of $\mathrm{CO}_{2}$-enhanced gas on lipid production was investigated by Hosseini et al. [13].

\subsection{Microalgae Cultivation}

Microalgae have been cultivated in open or closed systems-photobioreactors. The three main types of closed systems used for microalgae cultivation are tubular, vertical column, and flat panel bioreactors. The advantages and disadvantages of the used systems and how to select the system most suitable for algae production are discussed in many papers [14-18].

The bubble column is the basic type of vertical column-based reactor that is traditionally used in the chemical industry in operations, accompanied by intensive mass and heat transfer between phases such as oxidation, chlorination, alkylation, polymerization, and hydrogenation. The heat transfer in a bubbled column was investigated in coalescent [19] and non-coalescent liquids [20] for various superficial velocities. The airlift reactors (ALRs) were derived from bubble columns to achieve a more homogeneous flow pattern [21]. The airlift reactors consist of two zones: (i) An aerated zone called a riser, in which gas is sparged into the liquid; and (ii) a no-aerated zone called a downcomer. The zones can be formed in one column (internal-loop airlift) by division of column volume by a draft tube or by splitting baffle. The liquid phase can be sparged inside the draft tube (central aeration) or outside the tube in the annulus (perimeter aeration, annulus sparged). Unlike this, in the external-loop reactors, the riser and the downcomer are two physically separated columns whose upper and bottom parts are connected. According to Assunção and Malcata [18], industrial production remains challenging due to the constraints given by classical cultivation systems. They discussed the various nonconventional designs and modifications of conventional geometries which have been tested in recent years. The conventional internal loop airlift concentric draft tube is integrated and is modified with a static mixer or baffle (airlift baffled draft tube) to improve mixing efficiency or mechanical stirrers are added inside the draft tube or air is directly sparged through the inner cylinder. Kaewpintong et al. [22] investigated the effect of geometry and operation parameters on the cultivation performance of Haematococcus pluvialis producing astaxanthin, an antioxidant carotenoid. The experiments were carried out in a bubble column and internal-loop ALR. The highest cultivation performance was found in the ALR with $A_{D} / A_{R}$ of 3.2 for the lowest superficial gas velocity of $0.004 \mathrm{~m} / \mathrm{s}$. The higher aeration rate was found to be less effective, probably due to the higher cell sensitivity to shear stress caused by aeration. Ranjbar et al. [5] reported a higher production rate for astaxanthin in an internal-loop draft tube ALR compared to a bubble column. Chiu et al. [23] tested three types of photobioreactors: (i) Bubble column, (ii) internal airlift with a concentric tube, and (iii) internal airlift with a porous concentric tube for $\mathrm{CO}_{2}$ fixation. The internal airlift equipped with the porous concentric tube was found to be more efficient, reaching higher maximum biomass concentration and specific growth rate compared with the airlift with non-porous centric tube and bubble column. Hosseini et al. [11] analyzed the performance of bubble column and internal-loop airlift reactor with draught tube for biodiesel production. The higher biomass productivity was found in the bubble column. Unlike this, the higher lipid content leading to the higher lipid volumetric productivity was observed in the airlift reactor. Despite this finding, they considered the greater potential of bubble columns for large-scale biodiesel production.

It should be also noted that, besides cultivation, microalgae harvesting and dewatering [24] play an important role in the effective and sustainable production of microalgae biomass. Bělohlav and Jirout [25] developed a methodology for the design of harvesting and dewatering equipment that was based on the measured settling velocity and microalgae cell size. Acién et al. [26] analyzed costs of a real facility for the production of high-value microalgae biomass occurring in ten $3 \mathrm{~m}^{3}$ tubular photobioreactors operated in Almería (Spain). The microalgae were harvested by centrifugation and then dehydrated 
by freeze-drying. They reported a productivity of $90 \mathrm{t} /$ (ha.year) and a production cost of $69 € / \mathrm{kg}$. Labor and depreciation were found to be the major items. The centrifugal pumps recirculating the microalgae culture consume over 53\% approx. of the total electricity consumption. The air blowers are the second highest consumer, consuming $21 \%$ of electricity.

\subsection{Internal-Loop Airlift Reactor}

The advantages and limitations of airlift reactors adapted from the literature $[8,15,17$, 18,21] are presented in Table 1. The simple design, no moving parts, and relatively low shear stress are the biggest advantages of airlift reactors. In general, increasing the aeration rate improves mixing and mass transfer, but on the other side, shear stress increases what can be a problem for some cells sensitive to stress [22].

Table 1. Advantages and limitations of airlift reactors; adapted from $[8,15,17,18,21]$.

\begin{tabular}{|c|c|}
\hline Advantages & Limitations \\
\hline Simple design. & Compressed gas required. \\
\hline No moving parts. & Small illumination surface area. \\
\hline Good mixing due to circular mixing pattern. & Scale-up process is difficult. \\
\hline Intensive mass transfer. & $\begin{array}{l}\text { Decrease of illumination surface during } \\
\text { scale-up. }\end{array}$ \\
\hline Low shear stress. & $\begin{array}{l}\text { Increasing light path with increasing column } \\
\text { diameter. }\end{array}$ \\
\hline Efficient light penetration and utilization. & $\begin{array}{l}\text { Insufficient turbulence creation through airlift } \\
\text { operation. }\end{array}$ \\
\hline Exposure to light/dark cycles. & Risk of high shear stress on an algae culture. \\
\hline High biomass concentration. & $\begin{array}{l}\text { Restricted working volume by oxygen removal } \\
\text { capability of airlift process. }\end{array}$ \\
\hline $\begin{array}{l}\text { Good photosynthetic efficiency. } \\
\text { Low built area } \longrightarrow \text { High areal production. } \\
\text { Low fouling. }\end{array}$ & Photo-inhibition problems. \\
\hline
\end{tabular}

Gas injected into the riser zone induces a highly turbulent flow and high gas holdup. The hydrodynamics is similar to bubble columns. The liquid is returned to the riser inlet through the downcomer. The downcomer hydrodynamics can be approximated by the plug flow model. Zhang et al. [21] note that the novel ideas in downcomer design enabling to control flow may allow utilizing the potential of airlift reactors. The riser and the downcomer are connected at the upper part by the degassing section and by the bottom section at the lower part. The flow regimes in these sections can be modeled as continuously stirred reactors. In the degassing zone, depending on the geometry and operating conditions, the gas or its part escapes from the circulating liquid. Heijnen et al. [27] defined three typical flow regimes in downcomers of internal-loop ALRs depending on the increasing superficial velocity: (i) No bubbles enter the downcomer and gas escapes from the free liquid surface (regime I); (ii) part of the bubbles, mainly small bubbles, is entrained into the downcomer by the down-flowing liquid (regime II); and (iii) complete gas recirculation into the riser (regime III). The role of the bottom section is often mispriced. Koide et al. [28] reported increasing circulating liquid flow with increasing bottom clearance with riser diameter within the range $C_{B} / D_{R} \leq \frac{1}{2}$. For a higher ratio, the flow was unchanged. Lu et al. [29] studied the hydrodynamics and mass transfer characteristics in concentric tube airlift, modified square airlift reactor, and square bubble column. They reported larger $\varepsilon$, slightly longer homogenization time, and larger $k_{L} a$ for the square airlift reactor compared to standard airlift. Zhang et al. [30] investigated the effect of conical bottom and funnel-shaped internal above the tubular riser on hydrodynamics experimentally and by CFD. Installing the internals, the gas holdup was enhanced by a maximum of $15 \%$, and the turbulent kinetic energy can be reduced by a maximum of $7.8 \%$, which can be promising for stress-sensitive biological processes. The published data on the measurement 
methods, hydrodynamic characteristics, and modeling of flow dynamics in airlift reactors were summarized by Zhang et al. [21].

\subsection{Main Operational Parameters}

\subsubsection{Total Gas Holdup}

The gas holdup represents the gas volume fraction occupied in the gassed batch:

$$
\varepsilon_{G T}=\frac{V_{G}}{V_{b e d}}=\frac{V_{G}}{V_{G}+V_{L}+V_{S}},
$$

where $V_{G}$ is the volume of the gas phase, $V_{\text {bed }}$ is the total volume of a gassed batch. When the gas holdup is investigated in the gas-liquid-solid dispersion, the $V_{b e d}$ represents the sum of the volumes of the present phases.

The effect of superficial gas velocity $u_{S G}$ on gas holdup $\varepsilon_{G}$ has been usually described by the power-law function [31]:

$$
\varepsilon_{G}=C \cdot u_{S G}^{\alpha},
$$

where $u_{S G}$ is the superficial gas velocity related to the column diameter $\left(u_{S G C}\right)$ or riser diameter $\left(u_{S G R}\right)$, and $C$ and $\alpha$ are empirical constants depending on gas and liquid physical properties, hydrodynamic regime, and column geometry. The selected published correlations adapted from the literature [19,31-35] are presented in Table 2.

\begin{tabular}{|c|c|}
\hline Source & Correlation \\
\hline \multirow[t]{6}{*}{$\begin{array}{l}\text { Lu et al. } \\
\text { [29] }\end{array}$} & $\begin{array}{l}\text { Concentric tube ALR. } \mathrm{D}_{\mathrm{D}}=0.188 \mathrm{~m}, \mathrm{~A}_{\mathrm{R}} / \mathrm{A}_{\mathrm{D}}=0.695 \text { and } 1.38 \text {. } \\
\text { Gas distribution: Single nozzle. } \\
\text { Air-water system. }\end{array}$ \\
\hline & $\varepsilon_{G T}=0.035 \times u_{S G C} 0.647 \times\left(\mathrm{A}_{\mathrm{R}} / \mathrm{A}_{\mathrm{D}}\right)^{-0.085}$ \\
\hline & $0.02<u_{S G C}(\mathrm{~m} / \mathrm{s})<0.1$ \\
\hline & $\begin{array}{l}\text { Square airlift with concentric tube; } W=0.167 \mathrm{~m} ; \mathrm{A}_{\mathrm{R}} / \mathrm{A}_{\mathrm{D}}=0.695 \text { and 1.38. Gas } \\
\text { distribution: Single nozzle. } \\
\text { Air-water system. }\end{array}$ \\
\hline & $\varepsilon_{G T}=0.046 \times u_{S G C}{ }^{0.58} \times\left(\mathrm{A}_{\mathrm{R}} / \mathrm{A}_{\mathrm{D}}\right)^{-0.072}$ \\
\hline & $0.02<u_{S G C}(\mathrm{~m} / \mathrm{s})<0.1$ \\
\hline \multirow[t]{3}{*}{ Chisti [31] } & $\begin{array}{l}\text { Concentric tube ALR } \\
\text { Gas distribution: Perforated plate }\left(40 \text { holes, } \mathrm{d}_{\mathrm{h}}=1 \mathrm{~mm}\right) \\
\text { Air-liquid system. Liquids: Water, salt solution. }\end{array}$ \\
\hline & $\varepsilon=1.488 \times u_{S G C}{ }^{0.892} ;$ bubble flow, perforated plate. \\
\hline & $\varepsilon=0.371 \times u_{S G C}{ }^{0.430} ;$ coalesced bubble flow, perforated plate. \\
\hline \multirow[t]{5}{*}{$\begin{array}{l}\text { Juraščík } \\
\text { et al. [32] }\end{array}$} & $\begin{array}{l}\text { Concentric tube ALR. Gas distribution: Perforated plate. } \\
\text { Air-water system. } \\
\text { ALR1: } V=12 \mathrm{dm}^{3}, D_{C}=0.108 \mathrm{~m}, \mathrm{~A}_{D} / \mathrm{A}_{R}=1.23 \\
\text { ALR2: } V=40 \mathrm{dm}^{3}, \mathrm{D}_{C}=0.157 \mathrm{~m}, \mathrm{~A}_{\mathrm{D}} / \mathrm{A}_{\mathrm{R}}=0.95 \\
\text { ALR3: } \mathrm{V}=195 \mathrm{dm}^{3}, \mathrm{D}_{C}=0.294 \mathrm{~m}, \mathrm{~A}_{\mathrm{D}} / \mathrm{A}_{\mathrm{R}}=1.01\end{array}$ \\
\hline & $\varepsilon_{G T}=0.999 \times u_{S G R}{ }^{2 / 3} \times\left(1+\mathrm{A}_{\mathrm{D}} / \mathrm{A}_{\mathrm{R}}\right)^{-1} ; \mathrm{V}=12 \mathrm{dm}^{3}$ \\
\hline & $\varepsilon_{G T}=0.946 \times u_{S G R}{ }^{2 / 3} \times\left(1+A_{D} / A_{R}\right)^{-1} ; \mathrm{V}=40 \mathrm{dm}^{3}$ \\
\hline & $\varepsilon_{G T}=1.060 \times u_{S G R}{ }^{2 / 3} \times\left(1+A_{D} / A_{R}\right)^{-1} ; \mathrm{V}=195 \mathrm{dm}^{3}$ \\
\hline & $u_{S G C} \leq 0.065 \mathrm{~m} / \mathrm{s}$ \\
\hline
\end{tabular}

Table 2. Total gas holdup $\varepsilon_{G T}$ : selected published correlations; adapted from [19,31-35]. 
Table 2. Cont.

\begin{tabular}{|c|c|}
\hline Source & Correlation \\
\hline \multirow[t]{4}{*}{$\begin{array}{l}\text { Albijanić } \\
\text { et al. [33] }\end{array}$} & $\begin{array}{l}\text { Concentric-tube ALR with spherical bottom, } \mathrm{D}_{\mathrm{D}}=\mathrm{D}_{\mathrm{C}}=106 \mathrm{~mm}, \mathrm{D}_{\mathrm{R}} / \mathrm{D}_{\mathrm{C}}=0.51 \text {. } \\
\text { Gas distribution: Single orifice }\left(\mathrm{d}_{\mathrm{h}}=4 \mathrm{~mm}\right) \text {. } \\
\text { Air-liquid system; Liquids: Water, an aqueous solution of methanol, ethanol, } \\
\text { n-propanol, isopropanol, and n-butanol ( } 1 \mathrm{wt} \%) \text {. }\end{array}$ \\
\hline & $0.0025<u_{S G C}(\mathrm{~m} / \mathrm{s})<0.05$ \\
\hline & $\varepsilon_{G T}=1.65 \times u_{S G C}{ }^{0.97} \times\left[1+\left(-{\mathrm{d} \sigma / \mathrm{dc}_{\mathrm{A}}}\right)^{0.20}\right]^{1.52}$ \\
\hline & $\begin{array}{l}\left.\mathrm{c}_{\mathrm{A}} \text {-alcohol concentration (wt } \%\right) \\
\left(\mathrm{d} \sigma / \mathrm{dc}_{\mathrm{A}}\right) \text { - surface tension gradient }\end{array}$ \\
\hline \multirow[t]{4}{*}{$\begin{array}{l}\text { Gavrilescu } \\
\text { and } \\
\text { Tudose } \\
{[34]}\end{array}$} & $\begin{array}{l}\text { Concentric tube airlift; } D_{R}=0.1 \div 0.6 \mathrm{~m} . \mathrm{D}_{\text {char }}=\mathrm{D}_{R} . \\
\text { Gas distribution: Perforated plate sparger }\left(100 \times \mathrm{d}_{h}=2 \mathrm{~mm}\right) \text {, multiring sparger } \\
\left(\mathrm{d}_{\mathrm{h}}=3.5 \mathrm{~mm}\right) . \\
\text { Air-water system. }\end{array}$ \\
\hline & $\varepsilon_{G T}=3 \times \mathrm{Fr}_{\mathrm{R}}{ }^{1.2} \times \mathrm{B}^{-0.13} \times \mathrm{Y}^{-0.2} \times \mathrm{T}^{-0.6} \times \mathrm{R}^{-0.16}$ \\
\hline & $\begin{array}{l}5 \cdot 10^{-3}<\mathrm{Fr}_{\mathrm{R}}<110 \cdot 10^{-3}, 0.5<\mathrm{B}<3.8,0.333<\mathrm{Y}<1.267,1<\mathrm{T}<3.8,0.1<\mathrm{R}<0.9, \\
\mathrm{~A}_{\mathrm{D}} / \mathrm{A}_{\mathrm{R}} \geq 1, u_{S G R} \leq 0.11 \mathrm{~m} / \mathrm{s}\end{array}$ \\
\hline & $\begin{array}{l}B \text { - bottom spatial ratio }\left(B=C_{R B} / D_{R}\right) \\
R \text {-downcomer resistance flow ratio }\left(R=A_{D} / A_{R}\right) \\
T \text {-top spatial ratio }\left(T=C_{R U} / D_{R}+1\right) \\
Y \text {-gas separator ratio }\left(Y=\left(C_{R U}+D_{R}\right) / D_{S}\right)\end{array}$ \\
\hline \multirow[t]{3}{*}{$\begin{array}{l}\text { Gouveia } \\
\text { et al. [35] }\end{array}$} & $\begin{array}{l}\text { Concentric-draft tube ALR, annulus-sparged ALR; } A_{D} / A_{R}=0.63 \text {. } \\
D_{C}=0.100 \mathrm{~m} ; D_{D}=D_{T}=0.080 \mathrm{~m}, D_{\text {char }}=D_{\text {Rekv }} \text { (riser equivalent diameter). } \\
\text { Gas distribution: Ring with } 35 \text { holes }\left(d_{h}=0.7 \mathrm{~mm}\right) \\
\text { Air-water system. }\end{array}$ \\
\hline & $\varepsilon_{G T}=1.32 \times \mathrm{Fr}_{\mathrm{R}}{ }^{0.77} \times \mathrm{B}^{0.39} \times \mathrm{T}^{0.08}$ \\
\hline & $0.0126<u_{S G R}(\mathrm{~m} / \mathrm{s})<0.0440$ \\
\hline
\end{tabular}

\subsubsection{Homogenization Time}

The homogenization time is one of the important parameters for the design of photobioreactors. Shorter homogenization time indicates intensive mixing and enables to reach a faster homogeneous concentration distribution. The homogenization time is defined as the time required to achieve a homogenous mixture after the injection of a tracer solution [15]. Sanchéz Mirón et al. [36] tested the correlation proposed by Bando et al. [37] in the draft tube airlift reactor of $0.193 \mathrm{~m}$ in reactor diameter. They found the tested correlation overpredicted the time for the column superficial gas velocity $u_{S G C}$ in the range from 0 to $0.01 \mathrm{~m} / \mathrm{s}$, where the mixing is most sensitive to aeration velocity. The selected published correlations for homogenization time adapted from the literature [29,37-39] are presented in Table 3. 
Table 3. Homogenization time $t_{H}$-selected published correlations; adapted from [29,37-39].

\begin{tabular}{|c|c|}
\hline Source & Correlation \\
\hline \multirow[t]{6}{*}{$\begin{array}{l}\text { Lu et al. } \\
\text { [29] }\end{array}$} & $\begin{array}{l}\text { Concentric tube } A L R ; D_{D}=0.188 m, A_{R} / A_{D}=0.695 \text { and } 1.38 . \\
\text { Gas distribution: Single nozzle. } \\
\text { Air-water system. }\end{array}$ \\
\hline & $t_{H}(\mathrm{~s})=45.70 \times u_{S G C}{ }^{-0.377} \times\left(\mathrm{A}_{\mathrm{R}} / \mathrm{A}_{\mathrm{D}}\right)^{-0.319}$ \\
\hline & $0.02<u_{S G C}(\mathrm{~m} / \mathrm{s})<0.1$ \\
\hline & $\begin{array}{l}\text { Square airlift with concentric tube; } W=0.167 \mathrm{~m} ; \mathrm{A}_{\mathrm{R}} / \mathrm{A}_{\mathrm{D}}=0.695 \text { and } 1.38 \text {. Gas } \\
\text { distribution: Single nozzle. } \\
\text { Air-water system. }\end{array}$ \\
\hline & $t_{H}(\mathrm{~s})=53.15 \times u_{S G C}-0.377 \times\left(\mathrm{A}_{\mathrm{R}} / \mathrm{A}_{\mathrm{D}}\right)^{-0.269}$ \\
\hline & $0.02<u_{S G C}(\mathrm{~m} / \mathrm{s})<0.1$ \\
\hline \multirow[t]{3}{*}{$\begin{array}{l}\text { Bando } \\
\text { et al. [37] }\end{array}$} & $\begin{array}{l}\text { Concentric tube airlift; } \mathrm{D}_{\mathrm{C}}(\mathrm{m}) / \mathrm{D}_{\mathrm{T}}(\mathrm{m})=0.164 / 0.094 ; 0.300 / 0.164 ; 0.500 / 0.300 \\
\text { Gas distribution: perforated plate }\left(\mathrm{d}_{\mathrm{h}}=3 \mathrm{~mm}\right) \\
\text { Air-water system. }\end{array}$ \\
\hline & $\begin{array}{l}t_{H}(\mathrm{~s})=\mathrm{C} \times u_{S G C}{ }^{-0.5} \times \mathrm{D}_{\mathrm{C}}{ }^{1.4} \times\left(\mathrm{H}_{\mathrm{G}+\mathrm{L}} / \mathrm{D}_{\mathrm{C}}\right)^{1.2} \times\left(\mathrm{D}_{\mathrm{T}} / \mathrm{D}_{\mathrm{C}}\right)^{-1.4} \times(1- \\
\left.\mathrm{D}_{\mathrm{T}} / \mathrm{D}_{\mathrm{C}}\right)^{-1.1}\end{array}$ \\
\hline & $\begin{array}{l}\mathrm{C}=2.2 \text { for draft tube sparged ALR or } \mathrm{C}=2.6 \text { for annulus sparged } \mathrm{ALR} ; 0.114 \leq \mathrm{D}_{\mathrm{C}} \\
\leq 0.50 \mathrm{~m} ; 5 \leq \mathrm{H}_{\mathrm{G}+\mathrm{L}} / \mathrm{D}_{\mathrm{C}} \leq 40 ; 0.4 \leq \mathrm{D}_{\mathrm{T}} / \mathrm{D}_{\mathrm{C}} \leq 0.8 \text {. }\end{array}$ \\
\hline \multirow[t]{5}{*}{$\begin{array}{l}\text { Gavrilescu } \\
\text { and } \\
\text { Tudose } \\
{[38]}\end{array}$} & $\begin{array}{l}\text { Concentric draft tube ALR; } D_{R}=0.1 \div 0.6 \mathrm{~m} . \mathrm{D}_{\text {char }}=D_{R} . \\
\text { Gas distribution: Perforated plate sparger }\left(100 \times \mathrm{d}_{h}=2 \mathrm{~mm}\right) \text {, multiring sparger } \\
\left(\mathrm{d}_{\mathrm{h}}=3.5 \mathrm{~mm}\right) . \\
\text { Air-water system. }\end{array}$ \\
\hline & a) bubble and transition flow regime $\left(u_{S G R}<0.08 \mathrm{~m} / \mathrm{s}\right)$ \\
\hline & $t_{H}(\mathrm{~s})=4.6 \times \mathrm{R}^{-0.47} \times \mathrm{B}^{-1.10} \times \mathrm{T}^{-0.64} \times \mathrm{Fr}_{\mathrm{R}}-1.11$ \\
\hline & b) churn-turbulent regime $\left(u_{S G R}>0.08 \mathrm{~m} / \mathrm{s}\right)$ \\
\hline & $t_{H}(\mathrm{~s})=4.6 \times \mathrm{R}^{-0.47} \times \mathrm{B}^{0.8 \mathrm{~T}} \times \mathrm{Fr}_{\mathrm{R}}-1.11$ \\
\hline \multirow[t]{3}{*}{$\begin{array}{l}\text { Petrović } \\
\text { et al. [39] }\end{array}$} & $\begin{array}{l}\text { Concentric tube ALR; } \mathrm{D}_{\mathrm{C}}=0.2 \mathrm{~m}, \mathrm{D}_{\mathrm{T}}=0.080,0.1 \text {, and } 0.15 \mathrm{~m} . \\
\text { Air-water system. }\end{array}$ \\
\hline & $t_{H}(\mathrm{~s})=53.5 \times u_{S G C}{ }^{-0.31} \times\left(\mathrm{H}_{\mathrm{T}} / \mathrm{D}_{\mathrm{C}}\right)^{0.12} \times \mathrm{V}_{\mathrm{R}}^{0.19} \times \mathrm{V}_{\mathrm{D}}{ }^{0.50} \times \mathrm{V}_{\mathrm{S}}^{-0.26}$ \\
\hline & $u_{S G C}(\mathrm{~m} / \mathrm{s})<0.08$ \\
\hline
\end{tabular}

\subsubsection{Overall Volumetric Mass Transfer Coefficient $k_{L} a$}

The mass transfer is most frequently described by the overall volumetric mass transfer coefficient $k_{L} a$. Koide et al. [40] investigated $k_{L} a$ coefficients in internal-loop ALRs and bubble columns of different sizes and gas distributor types for demineralized water and five Newtonian solutions and air as a gaseous phase. The $k_{L} a$ coefficient was found to be larger in ALR compared to the bubble column. Increasing $\mathrm{D}_{\mathrm{R}} / \mathrm{D}_{\mathrm{D}}$ ratio, the $k_{L} a$ coefficient decreases. Gavrilescu and Tudose [41] investigated the effect of top and bottom clearance and $A_{D} / A_{R}$ ratio on $k_{L} a$ coefficient in three concentric-tube ALRs of different scales (0.07, 2.50 , and $5.20 \mathrm{~m}^{3}$ ) in non-coalescent Newtonian fluid (sodium sulfite solution). Gouveia et al. [35] investigated the effects of riser superficial gas velocity, bottom clearance, and top clearance on $k_{L} a$ coefficient in the air-water system using sulfite oxidation method in an internal-loop ALR of $6 \mathrm{dm}^{3}$ volume with $\mathrm{A}_{\mathrm{D}} / \mathrm{A}_{\mathrm{R}}=0.63$. Juraščík et al. [32] investigated $k_{L} a$ coefficients in three airlift reactors of different sizes $\left(12 \mathrm{dm}^{3}, 40 \mathrm{dm}^{3}\right.$, and $\left.195 \mathrm{dm}^{3}\right)$. Cerri et al. [42] investigated the effects of riser superficial gas velocity and physical properties $\left(D_{L}, v, \rho\right.$, and $\left.\sigma\right)$ in three concentric tube ALRs of different sizes $\left(2,5\right.$, and $\left.10 \mathrm{dm}^{3}\right)$ with cross-piece type sparger. The experimental data obtained for eight Newtonian fluids and five non-Newtonian fluids were fitted using a correlation type originally proposed by Akita and Yoshida [43] for bubble columns. The effect of superficial gas velocity $u_{S G}$ on the overall volumetric mass transfer coefficient $k_{L} a$ has been usually also described by 
the power-law function. The selected published correlations for $k_{L} a$ adapted from the literature $[32,33,35,36,40-42,44,45]$ are presented in Table 4.

Table 4. Overall volumetric mass transfer coefficient $k_{L} a$-selected published correlations; adapted from $[32,33,35,36,40-42,44,45]$.

\begin{tabular}{|c|c|}
\hline Source & Correlation \\
\hline \multirow[t]{8}{*}{$\begin{array}{l}\text { Juraščík } \\
\text { et al. [32] }\end{array}$} & $\begin{array}{l}\text { Concentric tube ALR. } \\
\text { ALR1: } V=12 \mathrm{dm}^{3}, D_{C}=0.108 \mathrm{~m}, \mathrm{~A}_{\mathrm{D}} / \mathrm{A}_{\mathrm{R}}=1.23 ; \\
\text { ALR2: } V=40 \mathrm{dm}^{3}, \mathrm{D}_{C}=0.157 \mathrm{~m}, \mathrm{~A}_{\mathrm{D}} / \mathrm{A}_{\mathrm{R}}=0.95 ; \\
\text { ALR3: } V=195 \mathrm{dm}^{3}, \mathrm{D}_{C}=0.294 \mathrm{~m}, \mathrm{~A}_{\mathrm{D}} / \mathrm{A}_{\mathrm{R}}=1.01 ; \\
\text { Gas distribution: Perforated plate. } \\
\text { Air-water system. }\end{array}$ \\
\hline & $k_{L} a\left(\mathrm{~s}^{-1}\right)=0.473 \varepsilon_{G T}{ }^{1.2} ; \mathrm{V}=12 \mathrm{dm}^{3}$ \\
\hline & $k_{L} a\left(\mathrm{~s}^{-1}\right)=0.524 \varepsilon_{G T}{ }^{1.2} ; \mathrm{V}=40 \mathrm{dm}^{3}$ \\
\hline & $k_{L} a\left(\mathrm{~s}^{-1}\right)=0.541 \varepsilon_{G T^{1.2}} ; \mathrm{V}=195 \mathrm{dm}^{3}$ \\
\hline & $k_{L} a\left(\mathrm{~s}^{-1}\right)=0.401 u_{S G R}{ }^{0.8} \times\left(1+\mathrm{A}_{\mathrm{D}} / \mathrm{A}_{\mathrm{R}}\right)^{-1} ; \mathrm{V}=12 \mathrm{dm}^{3}$ \\
\hline & $k_{L} a\left(\mathrm{~s}^{-1}\right)=0.428 u_{S G R}{ }^{0.8} \times\left(1+A_{D} / A_{R}\right)^{-1} ; V=40 \mathrm{dm}^{3}$ \\
\hline & $k_{L} a\left(\mathrm{~s}^{-1}\right)=0.506 u_{S G R}{ }^{0.8} \times\left(1+\mathrm{A}_{\mathrm{D}} / \mathrm{A}_{\mathrm{R}}\right)^{-1} ; \mathrm{V}=195 \mathrm{dm}^{3}$ \\
\hline & $u_{S G C} \leq 0.065 \mathrm{~m} / \mathrm{s}$ \\
\hline \multirow[t]{4}{*}{$\begin{array}{l}\text { Albijanić } \\
\text { et al. [33] }\end{array}$} & $\begin{array}{l}\text { Concentric- tube ALR with spherical bottom, } D_{D}=D_{C}=106 \mathrm{~mm}, D_{R}=D_{T} \text {, } \\
D_{R} / D_{C}=0.51 ; D_{c h a r}=D_{C} \text {. } \\
\text { Gas distribution: Single orifice }\left(d_{h}=4 \mathrm{~mm}\right) \text {. } \\
\text { Air-liquid system; Liquids: Water, an aqueous solution of methanol, ethanol, } \\
\text { n-propanol, isopropanol, and n-butanol }(1 \mathrm{wt} . \%) \text {. }\end{array}$ \\
\hline & $0.0025<u_{S G C}(\mathrm{~m} / \mathrm{s})<0.05$ \\
\hline & $k_{L} a\left(\mathrm{~s}^{-1}\right)=0.028 \times u_{S G C} 0.77 \times\left[1+\left(-\mathrm{d} \sigma / \mathrm{dc}_{\mathrm{A}}\right)^{0.15}\right]^{0.71}$ \\
\hline & $\begin{array}{l}\mathrm{c}_{\mathrm{A}} \text {-alcohol concentration (wt \%) } \\
\left(\mathrm{d} \sigma / \mathrm{dc}_{\mathrm{A}}\right) \text { - surface tension gradient }\end{array}$ \\
\hline \multirow[t]{3}{*}{$\begin{array}{l}\text { Sanchez } \\
\text { Miron } \\
\text { et al. [36] }\end{array}$} & $\begin{array}{l}\text { Concentric draft tube ALR; } D_{C}=D_{D}=193 \mathrm{~mm}, D_{R}=D_{T}=144 \mathrm{~mm} \text {. } \\
\text { Gas distribution: Cross-piece type sparger }\left(13 \text { holes, } d_{h}=0.5 \mathrm{~mm}\right) . \\
\text { Air-liquid system. Liquids: Tap water, seawater. } \\
u_{S G C}(\mathrm{~m} / \mathrm{s})<0.03\end{array}$ \\
\hline & $k_{L} a\left(\mathrm{~s}^{-1}\right)=0.641 /\left(u_{S G C}-0.935-1\right)$ for tap water \\
\hline & $k_{L} a\left(\mathrm{~s}^{-1}\right)=0.865 /\left(u_{S G C}-0.964-1\right)$ for sea water \\
\hline \multirow[t]{5}{*}{$\begin{array}{l}\text { Luo et al. } \\
{[44]}\end{array}$} & $\begin{array}{l}\text { Concentric tube ALR; } \mathrm{D}_{\mathrm{R}}=\mathrm{D}_{\mathrm{C}}=0.284 \mathrm{~m}, \mathrm{D}_{\mathrm{D}}=\mathrm{D}_{\mathrm{T}}=0.07 \mathrm{~m}, \mathrm{C}_{\mathrm{TB}}=0.040 \mathrm{~m} \text {. } \\
\text { Annulus sparged ALR. } \\
\text { Gas distribution: Two-orifice nozzle }\left(\mathrm{d}_{\mathrm{h}}=2.6 \mathrm{~mm}\right) \text {, 4-orifice nozzle }(1.84 \mathrm{~mm}) \text {, } \\
\left.\text { O-ring distributor ( } 63 \text { holes, } \mathrm{d}_{\mathrm{h}}=1 \mathrm{~mm}\right) . \\
\text { Air-water system. }\end{array}$ \\
\hline & $k_{L} a\left(\mathrm{~s}^{-1}\right)=0.2557 u_{S G C^{0.8496}} ;$ 2-orifice nozzle \\
\hline & $k_{L} a\left(\mathrm{~s}^{-1}\right)=0.4661 u_{S G C^{0.8496}} ;$ 4-orifice nozzle \\
\hline & $k_{L} a\left(\mathrm{~s}^{-1}\right)=0.2557 u_{S G C^{0.8496}} ;$ O-ring nozzle \\
\hline & $0.0007 \leq u_{S G C}(\mathrm{~m} / \mathrm{s}) \leq 0.00281$ \\
\hline \multirow[t]{3}{*}{$\begin{array}{l}\text { Gouveia } \\
\text { et al. [35] }\end{array}$} & $\begin{array}{l}\text { Concentric-draft tube ALR, annulus-sparged ALR; } A_{D} / A_{R}=0.63 \text {. } \\
D_{C}=0.100 \mathrm{~m} ; D_{D}=D_{T}=0.080 \mathrm{~m}, D_{\text {char }}=D_{\text {Rekv }} \text { (riser equivalent diameter). } \\
\text { Gas distribution: Ring with } 35 \text { holes }\left(d_{h}=0.7 \mathrm{~mm}\right) \\
\text { Air-water system. }\end{array}$ \\
\hline & $\mathrm{Sh}_{\mathrm{R}}=7.16 \times 10^{6} \times \mathrm{Fr}_{\mathrm{R}}{ }^{1.121} \times \mathrm{B}^{0.201} \times \mathrm{T}^{0.410}$ \\
\hline & $0.0126<u_{S G R}(\mathrm{~m} / \mathrm{s})<0.0440 ; 40<k_{L} a\left(\mathrm{~h}^{-1}\right)<250$ \\
\hline
\end{tabular}


Table 4. Cont.

\begin{tabular}{|c|c|}
\hline Source & Correlation \\
\hline \multirow[t]{4}{*}{$\begin{array}{l}\text { Koide } \\
\text { et al. [40] }\end{array}$} & $\begin{array}{l}\text { Concentric draft tube ALR with flat bottom, } \mathrm{D}_{\mathrm{D}}=\mathrm{D}_{\mathrm{C}}, \mathrm{D}_{\mathrm{R}}=\mathrm{D}_{\mathrm{T}}, \mathrm{D}_{\text {char }}=\mathrm{D}_{\mathrm{C}} \text {. } \\
\text { Gas distributors: Single nozzle, perforated plate, porous glass plate } \\
\text { Air-liquid system, liquid: Water, an aqueous solution of glycerol, glycol, } \mathrm{BaCl}_{2} \text {, } \\
\mathrm{NaSO}_{4}, \mathrm{Na}_{2} \mathrm{SO}_{3} \text {. }\end{array}$ \\
\hline & $0.021 \leq u_{S G C}(\mathrm{~m} / \mathrm{s}) \leq 0.15 ; 0.1 \leq \mathrm{D}_{\mathrm{D}} \leq 0.3 \mathrm{~m} ; 0.06 \leq \mathrm{D}_{\mathrm{R}} \leq 0.19 \mathrm{~m}$ \\
\hline & $\mathrm{Sh}_{\mathrm{C}}=0.477 \cdot \times \varepsilon_{G T}{ }^{1.36} \times \mathrm{Sc}^{0.5} \times \mathrm{Ga}_{\mathrm{C}}{ }^{0.257} \times \mathrm{Bo}_{\mathrm{C}}{ }^{0.873} \times\left(\mathrm{D}_{\mathrm{T}} / \mathrm{D}_{\mathrm{C}}\right)^{-0.542}$ \\
\hline & $\begin{array}{l}369 \leq \mathrm{Sc} \leq 56,800 ; 1,360 \leq \mathrm{Bo}_{\mathrm{C}} \leq 12,200 ; 2.27 \cdot 10^{8} \leq \mathrm{Ga}_{\mathrm{C}} \leq 3.32 \cdot 10^{11} ; 0.471 \leq \\
\mathrm{D}_{\mathrm{T}} / \mathrm{D}_{\mathrm{C}} \leq 0.743 ; 0.037 \leq \varepsilon_{G T} \leq 0.21\end{array}$ \\
\hline \multirow[t]{3}{*}{$\begin{array}{l}\text { Gavrilescu } \\
\text { and } \\
\text { Tudose } \\
{[41]}\end{array}$} & $\begin{array}{l}\text { Concentric-draught tube ALR. } D_{R}=0.1 \div 0.6 \mathrm{~m} . \\
\text { Gas distribution: Perforated plate sparger }\left(100 \times \mathrm{d}_{\mathrm{h}}=2 \mathrm{~mm}\right) \text {, multiring sparger } \\
\left(\mathrm{d}_{\mathrm{h}}=3.5 \mathrm{~mm}\right) . \\
\text { Air-water system. }\end{array}$ \\
\hline & $\mathrm{Sh}_{\mathrm{R}}=1.204 \cdot 10^{6} \times \mathrm{Fr}_{\mathrm{R}}{ }^{0.9} \times \mathrm{Ga}_{\mathrm{R}}{ }^{0.01} \times \mathrm{T}^{-0.18} \times \mathrm{B}^{-0.1} \times \mathrm{Y}^{-1.70} \times \mathrm{R}^{-0.18}$ \\
\hline & $\begin{array}{l}5 \cdot 10^{-3}<\mathrm{Fr}_{\mathrm{R}}<110 \cdot 10^{-3}, 9 \cdot 10^{6}<\mathrm{Ga}_{\mathrm{R}}<3 \cdot 10^{9}, 0.5<\mathrm{B}<3.8,0.333<\mathrm{Y}<1.267,1<\mathrm{T}< \\
3.8,0.1<\mathrm{R}<0.9, \mathrm{~A}_{\mathrm{D}} / \mathrm{A}_{\mathrm{R}} \geq 1, u_{S G R} \leq 0.11 \mathrm{~m} / \mathrm{s}\end{array}$ \\
\hline \multirow[t]{3}{*}{$\begin{array}{l}\text { Cerri et al. } \\
{[42]}\end{array}$} & $\begin{array}{l}\text { Concentric tube airlift with flat bottom, } D_{D}=D_{C}, D_{R}=D_{T}, D_{\text {char }}=D_{R} . \\
D_{R} / D_{C}=0.6 ; 1.68 \leq A_{D} / A_{R} \leq 1.84 ; V=2,5 \text {, and } 10 \mathrm{dm}^{3} . \\
\text { Gas distribution: Cross-piece type sparger }\left(d_{h}=0.5 \mathrm{~mm}\right) \\
\text { Air-liquid system. Liquids: Newtonian fluids (water, aqueous solutions of glycerol) } \\
\text { and non-Newtonian fluids (aqueous solutions of xanthan gum). }\end{array}$ \\
\hline & $\mathrm{Sh}_{\mathrm{R}}=4.6 \times 10^{-5} \times \mathrm{Fr}_{\mathrm{R}}{ }^{0.642} \times \mathrm{Sc}^{0.779} \times \mathrm{Ga}_{\mathrm{R}}{ }^{0.673} \times \mathrm{Bo}_{\mathrm{R}}{ }^{0.245} \times \varepsilon_{G T}{ }^{0.2}$ \\
\hline & $\begin{array}{l}4.921<\mathrm{Sh}_{\mathrm{R}}<256,768 ; 0.011<\mathrm{Fr}_{\mathrm{R}}<0.143 ; 297<\mathrm{Sc}<27,544 ; 410<\mathrm{Bo}_{\mathrm{R}}<1.510 \\
1.4 \cdot 10^{7}<\mathrm{Ga}_{\mathrm{R}}<1.8 \cdot 10^{10} ; 0.009<\varepsilon_{G T}<0.170\end{array}$ \\
\hline \multirow[t]{4}{*}{$\begin{array}{l}\text { Koide } \\
\text { et al. [45] }\end{array}$} & $\begin{array}{l}\text { Concentric draft tube ALR with conical bottom, } \mathrm{D}_{\mathrm{D}}=\mathrm{D}_{\mathrm{C}}, \mathrm{D}_{\mathrm{R}}=\mathrm{D}_{\mathrm{T}}, \mathrm{D}_{\mathrm{char}}=\mathrm{D}_{\mathrm{C}} \text {. Gas } \\
\text { distributor: Perforated plate. } \\
\text { Air-liquid system, liquid: Water, an aqueous solution of glycerol, glycol, } \mathrm{BaCl}_{2} \text {, } \\
\mathrm{NaSO}_{4} \text {. }\end{array}$ \\
\hline & $0.021 \leq u_{S G C}(\mathrm{~m} / \mathrm{s}) \leq 0.15 ; 0.1 \leq \mathrm{D}_{\mathrm{D}} \leq 0.3 \mathrm{~m} ; 0.06 \leq \mathrm{D}_{\mathrm{R}} \leq 0.19 \mathrm{~m}$ \\
\hline & $\begin{array}{l}\mathrm{Sh}_{\mathrm{C}}=4.04 \cdot \times \varepsilon_{G T}{ }^{1.34} \times \mathrm{Sc}^{0.5} \times \mathrm{Ga}_{\mathrm{C}}{ }^{0.260} \times \mathrm{Bo}_{\mathrm{C}}{ }^{0.670} \times\left(\mathrm{D}_{\mathrm{T}} / \mathrm{D}_{\mathrm{C}}\right)^{-0.047} \times(1+ \\
\left.2.00 \varphi_{\mathrm{S}}{ }^{1.30}\right)^{-1}\end{array}$ \\
\hline & $\begin{array}{l}371 \leq \mathrm{Sc} \leq 55,200 ; 2,660 \leq \mathrm{Bo}_{\mathrm{C}} \leq 12,200 ; 2.35 \cdot 10^{8} \leq \mathrm{Ga}_{\mathrm{C}} \leq 3.29 \cdot 10^{11} ; \\
1.69 \cdot 10^{-11} \leq \mathrm{Mo} \leq 6.67 \cdot 10^{-7} ; 0.471 \leq \mathrm{D}_{\mathrm{T}} / \mathrm{D}_{\mathrm{C}} \leq 0.743 ; 0.0379 \leq \varepsilon_{G T} \leq 0.224 ; 0 \leq \varphi_{\mathrm{S}} \\
(v / v) \leq 0.20\end{array}$ \\
\hline
\end{tabular}

\subsubsection{Effect of Solid Phase}

Koide et al. [45] investigated the effect of column diameter, gas velocity, liquid properties, and size and concentration of gel particles in a conical draft tube ALR with a conical bottom. The solid phase concentration was varied in the range from 0 to $20 \mathrm{vol} . \%$. They found the presence of gel particles reduced the values of the gas holdup and the overall volumetric mass transfer coefficient. The degree of reduction increased with increasing solid concentration and was independent of gel particle diameter in the range from 1.88 to $3.98 \mathrm{~mm}$. Yang et al. [46] investigated the effect of superficial gas velocity and top clearance on hydrodynamics and mass transfer in the gas-liquid and gas-slurry system in internal loop airlift with draft tube $\left(D_{D} / D_{R}=140 / 280 \mathrm{~mm}\right)$ and perimeter aeration. The aluminum oxide particles with a diameter of $98.67 \mu \mathrm{m}$ were used as the solid phase. The experiments were carried out at a volumetric solid loading of $0.5 \%$. The effect of top clearance on the $k_{L} a$ coefficient was found when the superficial gas velocity was higher than $0.034 \mathrm{~m} / \mathrm{s}$. The increase of $k_{L} a$ coefficient in the gas-slurry system was approx. $8 \%$ for the superficial gas velocity higher than $0.034 \mathrm{~m} / \mathrm{s}$. Sastaravet et al. [47] investigated the effect of polypropylene particles of different shapes and solid loading on the bubble 
hydrodynamics and mass transfer in a bubble column and internal-loop airlift reactor with a splitting baffle. The enhancement of the $k_{L} a$ coefficient up to $38.5 \%$ was achieved in the airlift reactor when the solid particles were added. The solid particles shaped like cylinders and rings were found to be most effective for $k_{L} a$ enhancement.

\subsection{Motivation}

Based on the standard design, we designed a novel configuration of an internal jetloop airlift reactor. The gas separator was equipped with an adjustable deflector placed above the riser. Installing the deflector, the fluctuation of the dispersion level should be stabilized in the gas separator and the contact time between liquid and gas bubbles should be prolonged. The conical airlift bottom was used for better flow direction in the bottom section and elimination of particle accumulation in a dead zone when the flat bottom is used. The preliminary results were presented in our previous work [48].

This work aims to study the effects of riser superficial gas velocity $u_{S G R}$ and deflector clearance $C_{D}$ above a riser on total gas holdup $\varepsilon_{G T}$, homogenization time $t_{H}$, and overall volumetric liquid-phase mass transfer coefficient $k_{L} a$ in the two-phase gas-liquid system and three-phase gas-liquid-solid system in the range of riser superficial gas velocity up to $0.045 \mathrm{~m} / \mathrm{s}$.

\section{Materials and Methods}

\subsection{Experimental Apparatus}

The experiments were carried out in a laboratory conical jet-loop airlift bioreactor of $300 \mathrm{~mm}$ inner diameter and volume of $62.5 \mathrm{dm}^{3}$. The geometrical parameters are presented in Table 5. The tap water was used as a model liquid and the air was fed into the airlift reactor via a single nozzle having three orifices of $1 \mathrm{~mm}$ in hole diameter. The scheme of the experimental apparatus is depicted in Figure 1.

Table 5. Concentric jet-loop airlift bioreactor: Geometrical characteristics.

\begin{tabular}{ccc}
\hline Parameter & Symbol & This Work \\
\hline downcomer diameter & $\mathrm{D}_{\mathrm{D}}(\mathrm{mm})$ & 300 \\
\hline riser diameter & $\mathrm{D}_{\mathrm{R}}(\mathrm{mm})$ & 66 \\
\hline gas separator diameter & $\mathrm{D}_{\mathrm{S}}(\mathrm{mm})$ & 300 \\
\hline riser height & $\mathrm{H}_{\mathrm{R}}(\mathrm{mm})$ & 720 \\
\hline riser bottom clearance & $\mathrm{C}_{\mathrm{RB}}(\mathrm{mm})$ & 70 \\
\hline riser upper clearance & $\mathrm{C}_{\mathrm{RU}}(\mathrm{mm})$ & 200 \\
\hline deflector clearance & $\mathrm{C}_{\mathrm{D}}(\mathrm{mm})$ & $30,70,110,150$ \\
\hline unaerated liquid height & $\mathrm{H}_{\mathrm{L}}(\mathrm{mm})$ & 960 \\
\hline unaerated liquid volume & $\mathrm{V}_{\mathrm{L}}(\mathrm{m} 3)$ & 0.0625 \\
\hline
\end{tabular}




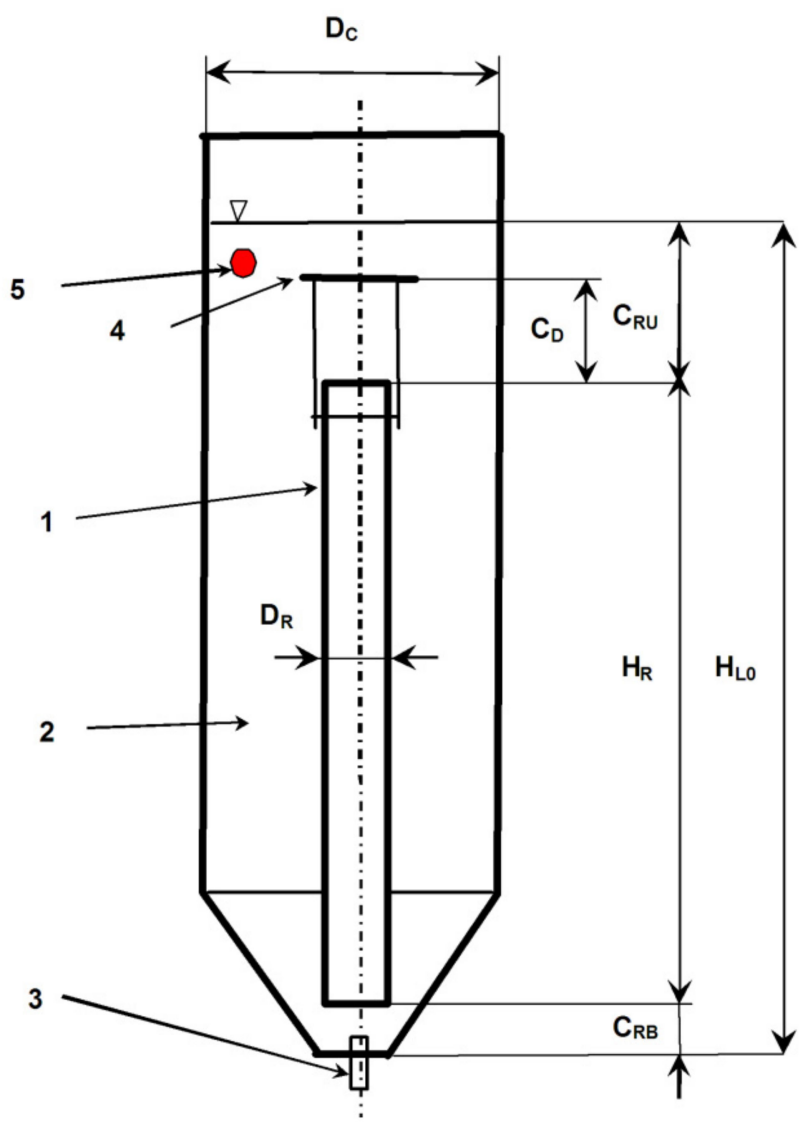

Figure 1. Scheme of the experimental apparatus: (1) Riser, (2) downcomer, (3) sparger, (4) deflector, (5) oxygen probe.

\subsection{Experimental Conditions}

The air-water system was used as a tested two-phase gas-liquid system. The extruded PVC rods of diameter $4 \mathrm{~mm}$ and length ranging from 2.5 to $4 \mathrm{~mm}$ were used as the model solid phase. The solid phase fraction used was $1 \% v / v$. The air flow rate was in the range of riser superficial gas velocity $u_{S G R}$ from 0.011 to $0.045 \mathrm{~m} / \mathrm{s}$. The airlift was operated in regime I according to the classification given by Heijnen et al. [27]. The experimental conditions are summarized in Table 6.

Table 6. Concentric jet-loop airlift bioreactor: Experimental conditions.

\begin{tabular}{ll}
\multicolumn{1}{c}{ Phase } & \multicolumn{1}{c}{ Properties } \\
\hline Gas phase & air $\left(\mathrm{T}=25 \pm 2{ }^{\circ} \mathrm{C}\right) ; u_{S G R}=0.011 ; 0.023 ; 0.034 ; 0.045 \mathrm{~m} / \mathrm{s}$ \\
Liquid phase & $\begin{array}{l}\text { tap water }\left(\mathrm{T}=25 \pm 2{ }^{\circ} \mathrm{C}\right) \\
\text { Solid phase }\end{array}$ \\
\hline
\end{tabular}

\subsection{Experimental Methods}

\subsubsection{Total Gas Holdup}

The gas holdup was determined visually by the measurement of the difference between the non-aerated liquid level and the aerated liquid level. The overall gas holdup $\varepsilon_{G T}$ was determined by measuring the bed height at a given superficial gas velocity as:

$$
\varepsilon_{G T}=\frac{H_{G+L+S}-H_{L+S}}{H_{G+L+S}},
$$

where $H_{G+L+S}$ is the gassed bed height, $H_{L+S}$ is the height of the liquid/suspension before aeration. 
The effects of riser superficial gas velocity $u_{S G R}$ and deflector clearance $C_{D}$ on the measured total gas holdup $\varepsilon_{G T}$ were correlated using the power-law function:

$$
\begin{gathered}
\varepsilon_{G T}=C \cdot u_{S G R}^{\alpha} \cdot C_{D}^{* \beta}, \\
C_{D}^{*}=C_{D} / C_{R U},
\end{gathered}
$$

where $C_{D}^{*}$ is the dimensionless deflector clearance; $C_{R U}$ is the riser upper clearance; $C, \alpha$ and $\beta$ are model parameters.

\subsubsection{Homogenization Time}

The homogenization time was measured by the decolorization technique [49] using $1 \mathrm{M} \mathrm{NaOH}$ and $10 \%$ wt. $\mathrm{H}_{2} \mathrm{SO}_{4}$. Phenolphthalein was used as an indicator.

The effects of riser superficial gas velocity $u_{S G R}$ and deflector clearance $C_{D}$ on the measured homogenization time $t_{H}$ were correlated using the power-law function:

$$
t_{H}=C \cdot u_{S G R}^{\alpha} \cdot C_{D}^{* \beta}
$$

Alternatively, the experimental data were successfully correlated using a combined exponential- and power-law function:

$$
t_{H}=C \cdot \exp \left(\alpha \cdot u_{S G R}\right) \cdot\left(1-C_{D}^{*}\right)^{\beta} .
$$

\subsubsection{Overall Volumetric Liquid-Phase Mass Transfer Coefficient $k_{L} a$}

The overall volumetric mass transfer coefficient $k_{L} a$ was determined using the unsteady dynamic method from the oxygen probe response curve [50]. The water was deoxygenated by nitrogen $\mathrm{N}_{2}$. Then the water was re-oxygenated by air. The time evolution of dissolved oxygen concentration was measured by an oxygen probe. Applying film theory, the oxygen transfer rate (OTR) between gas and liquid can be expressed in a given spot as follows:

$$
\text { OTR }=\frac{d c_{L}}{d t}=k_{L} \cdot \frac{S_{G}}{V_{L}} \cdot\left(c_{L}^{*}-c_{L}\right)=k_{L} \cdot a \cdot\left(c_{L}^{*}-c_{L}\right),
$$

where $k_{L}$ is the overall mass transfer coefficient related to liquid-phase side, $S_{G}$ is the gas-to-liquid interfacial area, $c_{L}$ is the mass concentration of dissolved oxygen in the liquid, $c_{L}^{*}$ is the mass concentration of dissolved oxygen in the liquid at saturation, a is the specific gas to liquid interfacial area. In practice, the product of $k_{L}$ and a, called volumetric mass transfer coefficient, has been evaluated due to the experimental difficulties of determination of $k_{L}$ and separately. Assuming that $c_{L}^{*}=$ const. in a given spot (i.e., the oxygen fraction in air bubbles in a given spot is practically stable during absorption), the following relation can be obtained by integration of Equation (3):

$$
\frac{c_{L}^{*}-c_{L}(t)}{c_{L}^{*}-c_{L}(t=0)}=\exp \left(-k_{L} \cdot a \cdot t\right)
$$

where $t$ is the time, $c_{L}(t)$ is the dissolved oxygen concentration at time $t$, and $c_{L}(t=0)$ is the initial dissolved oxygen concentration.

In this work, the response time of the oxygen probe was taken into account. The $k_{L} a$ coefficient was determined using the following relation [51]:

$$
\frac{c_{L}^{*}-c_{L}(t)}{c_{L}^{*}-c_{L}(t=0)}=\frac{1}{1-k_{L} a \cdot \tau} \cdot\left[\exp \left(-k_{L} a \cdot t\right)-k_{L} a \cdot \tau \cdot \exp (-t / \tau)\right],
$$

where $\tau$ is the response time of the oxygen probe. The dissolved oxygen concentration in the liquid was measured by an oxygen optiluminiscence probe FDO 925 (WTW Germany). The response time of this probe is $30 \mathrm{~s}$. The oxygen probe was placed in the middle of the annulus and the measuring part was immersed $25 \mathrm{~mm}$ below the liquid level. 
The $k_{L} a$ coefficient was obtained using Equation (5) by the fitting of the time course of dissolved oxygen concentration using nonlinear regression. For $k_{L} a$ determination, only part of the data record of $c_{L}(t)$ was used. The time dependence of dissolved oxygen was transformed into the time dependence of the relation $\ln \left(c_{L}^{*}-c_{L}(\mathrm{t})\right)$. The part of the record having a linear course of the time dependence of the relation $\ln \left(c_{L}^{*}-c_{L}(t)\right)$ was identified as relevant for $k_{L} a$ determination.

For $k_{L} a$ data correlation, the $k_{L} a$ value obtained at experimental temperature $\mathrm{T}$ has to be corrected to the reference temperature $T_{r e f}$ [52]. The $k_{L} a$ value obtained at temperature $T$ was corrected to the reference temperature $T=20^{\circ} \mathrm{C}$ as follows [52]:

$$
\left(k_{L} a\right)_{20}=\left(k_{L} a\right)_{T} \cdot C^{20-T\left({ }^{\circ} \mathrm{C}\right)},
$$

where $\left(k_{L} a\right)_{T}$ is the mass transfer coefficient measured at temperature $T,\left(k_{L} a\right)_{20}$ is the mass transfer coefficient at reference temperature $20^{\circ} \mathrm{C}$, and $\mathrm{C}$ is the empirical temperature correction factor. Bewtra et al. [52] present factor C as 1.0192 and Nogaj and Hurwitz [53] presented the value 1.024 as the factor. It should be noted that this approach has been critically discussed [54]. Nevertheless, in this work, the measured values of the overall volumetric mass transfer coefficient were corrected onto $20^{\circ} \mathrm{C}$ using this approach and the factor of 1.024 .

The effects of riser superficial gas velocity $u_{S G R}$ and deflector clearance $C_{D}$ on the temperature corrected overall volumetric mass transfer coefficient $k_{L} a$ were correlated using the power-law function:

$$
k_{L} a=C \cdot u_{S G R}^{\alpha} \cdot C_{D}^{* \beta} .
$$

Alternatively, the experimental data were successfully correlated using a combined exponential- and power-law function:

$$
k_{L} a=C \cdot \exp \left(\alpha \cdot u_{S G R}\right) \cdot C_{D}^{* \beta} .
$$

\subsubsection{Statistical Analysis}

The effects of riser superficial gas velocity $u_{S G R}$ and deflector clearance $C_{D}$ on the properties investigated were analyzed statistically using hypothesis testing [55]. For this analysis, the power-law dependence is assumed. The statistical method of hypothesis testing can estimate whether the differences between the predicted power-law exponent $\alpha_{\text {pred }}$ and the evaluated power-law exponent $\alpha_{\text {calc }}$ from the measured data are negligible. The testing characteristics $t$ is calculated:

$$
\begin{gathered}
t=\left(\alpha_{\text {calc }}-\alpha_{\text {pred }}\right) / s_{\alpha} . \\
s_{\propto}=\sqrt{\frac{\sum_{i}^{m} y_{\text {exp }, i}^{2}-\log C \cdot \sum_{i}^{m} y_{\text {exp }, i}-\alpha \cdot \sum_{i}^{m} y_{\text {exp }, i} \cdot x_{\text {exp }, i}}{(m-2) \cdot\left[\sum_{i}^{m} x_{\text {exp }, i}^{2}-\left(\sum_{i}^{m} x_{\text {exp }, i}\right)^{2} / m\right]}},
\end{gathered}
$$

where $y_{\text {exp, } i}$ is the experimental value of an investigated property for the independent variable $x_{i}, \mathrm{C}$ is the constant of proportionality of power-law function, $s_{\alpha}$ is the standard deviation of a power-law exponent $\alpha, \mathrm{m}$ is the number of experimental data items. If the absolute value of the calculated testing characteristics $|t|$ is less than the critical value of the $\mathrm{t}$-distribution for $(\mathrm{m}-2)$ degrees of freedom and significance level $\alpha$, the difference between $\alpha_{\text {calc }}$ and $\alpha_{\text {pred }}$ can be assumed statistically negligible. The significance level $\alpha=0.05$ [56] was used for the determination of the critical $t$-value. The $t$-distribution coefficient $t_{(m-2), \alpha}$ is 4.3027 for four riser superficial gas velocities, and the significance level $\alpha=0.05$.

Three statistical parameters were used as evaluating parameters of the proposed correlations, which are computed as follows [57]: 
(i) average absolute error (AAE):

$$
\operatorname{AAE}(\%)=\frac{1}{m} \cdot \sum_{i=1}^{m}\left|\frac{y_{\text {pred }, i}-y_{\text {exp }, i}}{y_{\text {exp }, i}}\right| \cdot 100,
$$

(ii) average biased error (ABE):

$$
\operatorname{ABE}(\%)=\frac{1}{m} \cdot \sum_{i=1}^{m} \frac{y_{\text {pred }, i}-y_{\text {exp }, i}}{y_{\text {exp }, i}} \cdot 100,
$$

(iii) coefficient of determination $\left(R^{2}\right)$ :

$$
R^{2}=1-\sum_{i=1}^{m} \frac{\left(y_{\text {pred }, i}-y_{\text {exp }, i}\right)^{2}}{\left(y_{\text {exp }, i}-\bar{y}_{\text {exp }}\right)^{2}}
$$

where $y_{\text {pred, }, i}$ is the property value predicted by proposed correlation, $\bar{y}_{\exp }$ is the average of experimental property values. These three statistical criteria are employed to assess the applicability of proposed or tested correlations [58]. The average absolute error (AAE) measures the degree of closeness between the predicted and measured results [57]. A smaller value of AAE indicates higher accuracy of the proposed correlation [58]. The average biased error (ABE) indicates the degree of overestimation and underestimation of proposed or tested correlation [57]. The positive value of $\mathrm{ABE}$ indicates an overall overestimation, whereas a negative value of $A B E$ indicates an overall underestimation [58]. The coefficient of determination ( $R^{2}$-value) is used to determine the degree of goodness and accuracy of proposed or tested correlation [57]. A higher $R^{2}$-value indicates a better fitting quality of correlation used [58]. The proposed or tested correlation is considered the best fitting model if the AAE and ABE values tend to zero and $R^{2}$-value is close to 1 [57].

\section{Results}

\subsection{Total Gas Holdup}

The measured values of total gas holdup are shown in Figure 2 as a function of dimensionless deflector clearance for the gas-liquid and gas-liquid-solid systems. For comparison, the values calculated using the proposed correlation (4) are shown also. For the gas-liquid-solid system, the riser superficial velocity of $0.011 \mathrm{~m} / \mathrm{s}$ was insufficient to suspend all solid particles.

As was expected, reducing the deflector clearance, the total gas holdup decreases for the gas-liquid system. Unlike this, the weak effect of deflector clearance was observed for the gas-liquid-solid system, especially for higher $u_{S G R}$. The higher gas holdup was observed for the lowest $u_{S G R}$ and the smallest deflector clearance. Competitive impingement between aeration, particle suspension, and flow restriction due to changing deflector clearance may result in this dissimilar behavior. It can be indicated by unconsolidated values of $\alpha$-exponent and $\beta$-exponent (Tables 7 and 8 in detail). 


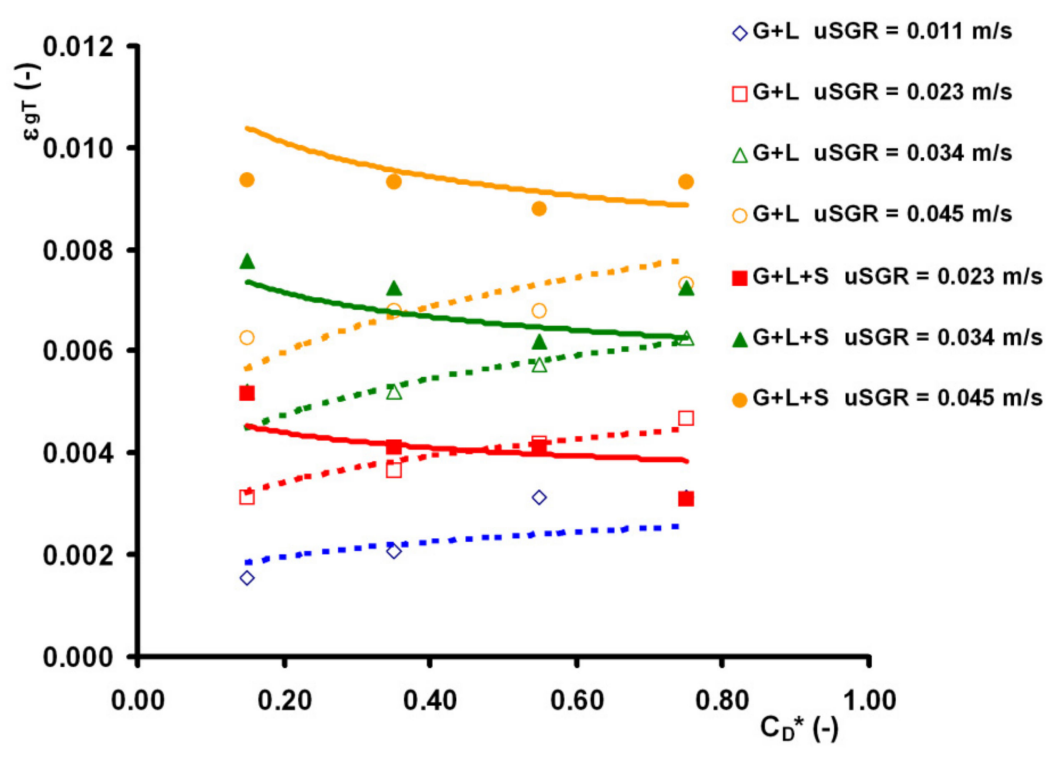

Figure 2. Total gas holdup $G T$ : Effect of dimensionless deflector clearance: Gas-liquid system (empty symbols), gas-liquid-solid system (full symbols), correlation (4) for gas-liquid system (dotted line), correlation (4) for gas-liquid-solid system (full line).

The values of the power law exponent for superficial gas velocity reported in the literature range usually in the range from 0.647 to 1.2 for the gas-liquid system. Analyzing overall data, the $\alpha$-values of 0.802 and 1.187 were obtained for the gas-liquid system and gas-liquid-solid system, respectively. The applicability of the $\alpha$-values of 0.8 and 1.2 for gas-liquid system and gas-liquid-solid system, respectively, was tested using the hypothesis test for each deflector clearance separately. The hypothesis testing was done for both the gas-liquid system and the gas-liquid-solid system. The hypothesis test results are presented in Table 7 . For illustration, the average values of the calculated $t$ values are presented here also. Except for $C_{D}^{*}=0.75$ in the gas-liquid system, the proposed $\alpha$-values were statistically confirmed for both systems.

The effect of deflector clearance on total gas holdup was tested for each riser superficial gas velocity. In this case, the independence of total gas holdup of the deflector clearance was tested as the hypothesis, that is, $\varepsilon_{G T}=B$. $\left(C_{D}^{*}\right)^{0}=$ const. (i.e., $\beta_{\text {pred }}=0$ ). The hypothesis test results are presented in Table 8 . Statistically, the effect of deflector clearance can be neglected for the gas-liquid-solid system, and at higher $u_{S G R}$ in the gas-liquid system. Analyzing the overall data, the $\beta$-values of 0.205 and -0.125 were obtained for the gasliquid system and gas-liquid-solid system, respectively. For the data correlation, the $\beta$-values of 0.2 and -0.1 were assumed for the gas-liquid system and gas-liquid-solid system, respectively. 
Table 7. Total gas holdup $\varepsilon_{G T}$ : Results of the hypothesis testing-effect of riser superficial velocity $u_{S G R}$ for deflector clearance $C_{D}^{*}=$ const.

\begin{tabular}{|c|c|c|c|c|}
\hline & Gas-Liquid System & & $\begin{array}{c}\text { Gas-Liquid-Solid } \\
\text { System }\end{array}$ & \\
\hline Hypothesis Testing & $\begin{array}{c}\text { Relation: } \\
\varepsilon_{G T}=\mathbf{B}_{\mathrm{R}} \cdot\left(u_{S G R}\right)^{\alpha} \\
\alpha_{\text {calc }}(-)\end{array}$ & $\begin{array}{c}\text { Hypothesis }{ }^{1}: \\
\varepsilon_{G T}=\mathrm{B}_{\mathrm{H}} \cdot\left(u_{S G R}\right)^{0.8} \\
\mathrm{t} \text {-Characteristics } \\
|t|\end{array}$ & $\begin{array}{c}\text { Relation: } \\
\varepsilon_{G T}=\mathrm{B}_{\mathrm{R}} \cdot\left(u_{S G R}\right)^{\alpha} \\
\alpha_{\text {calc }}(-)\end{array}$ & $\begin{array}{c}\text { Hypothesis }{ }^{1}: \\
\varepsilon_{G T}=\mathbf{B}_{\mathbf{H}} \cdot\left(u_{S G R}\right)^{0.8} \\
\text { t-Characteristics } \\
|t|\end{array}$ \\
\hline$C_{D}^{*}=0.75$ & 0.621 & 9.7 (not acceptable) & 1.616 & 1.2 (acceptable) \\
\hline$C_{D}^{*}=0.55$ & 0.567 & 4.1 (acceptable) & 1.085 & 2 (acceptable) \\
\hline$C_{D}^{*}=0.35$ & 0.850 & 2.9 (acceptable) & 1.188 & 0.1 (acceptable) \\
\hline$C_{D}^{*}=0.15$ & 1.032 & 4 (acceptable) & 0.861 & 3.5 (acceptable) \\
\hline Overall data analysis & 0.802 & --- & 1.187 & --- \\
\hline
\end{tabular}

Table 8. Total gas holdup $\varepsilon_{G T}$ : Results of the hypothesis testing-effect of deflector clearance $\mathrm{C}_{\mathrm{D}}$ on superficial gas velocity $u_{S G R}=$ const.

\begin{tabular}{|c|c|c|c|c|}
\hline & Gas-Liquid System & & $\begin{array}{l}\text { Gas-Liquid-Solid } \\
\text { System }\end{array}$ & \\
\hline Hypothesis Testing & $\begin{array}{c}\text { Relation: } \\
\mathcal{E}_{G T}=\mathrm{B}_{\mathrm{R}} \cdot\left(C_{D}^{*}\right)^{\beta} \\
\beta_{\text {calc }}(-)\end{array}$ & $\begin{array}{c}\text { Hypothesis }{ }^{1:} \\
\varepsilon_{G T}=B_{\mathrm{H}} \cdot\left(C_{D}^{*}\right)^{0} \\
\mathrm{t}-\text { Characteristics } \\
|t|\end{array}$ & $\begin{array}{c}\text { Relation: } \\
\mathcal{E}_{G T}=\mathrm{B}_{\mathrm{R}} \cdot\left(C_{D}^{*}\right)^{\beta} \\
\beta_{\text {calc }}(-)\end{array}$ & $\begin{array}{c}\text { Hypothesis }{ }^{1}: \\
\varepsilon_{G T}=\mathrm{B}_{\mathrm{H}} \cdot\left(C_{D}^{*}\right)^{0} \\
\mathrm{t}-C^{0} \text { aracteristics } \\
|t|\end{array}$ \\
\hline$u_{S G R}=0.011 \mathrm{~m} / \mathrm{s}$ & 0.468 & 5.5 (not acceptable) & --- & --- \\
\hline$u_{S G R}=0.023 \mathrm{~m} / \mathrm{s}$ & 0.246 & 8.2 (not acceptable) & -0.275 & 3.3 (acceptable) \\
\hline$u_{S G R}=0.034 \mathrm{~m} / \mathrm{s}$ & 0.107 & 2.3 (acceptable) & -0.083 & 1.1 (acceptable) \\
\hline$u_{S G R}=0.045 \mathrm{~m} / \mathrm{s}$ & 0.085 & 4.1 (acceptable) & -0.017 & 0.6 (acceptable) \\
\hline Overall data analysis & 0.205 & --- & -0.125 & --- \\
\hline
\end{tabular}

The evaluated parameters of the power-law correlation (4), coefficient of determination $\left(R^{2}\right)$, average absolute error (AAE), and average bias error (ABE) are presented in Table 9 for the gas-liquid and gas-liquid-solid system. The low negative ABE value indicates only a low overall underestimation of total gas holdup by the proposed correlation (4). The comparison of experimental data and the correlation given by Equation (4) is presented in Figure 3 for both systems. The lines representing the relative error of $\pm 15 \%$ are shown also in Figure 3 for illustration.

Table 9. Total gas holdup $\varepsilon_{G T}$ : Evaluated parameters of correlation (4).

\begin{tabular}{lcccccc}
\hline \multicolumn{1}{c}{ System } & $\mathbf{C}^{\mathbf{1}}\left(\mathbf{( m / s ) ^ { - \boldsymbol { \alpha } } )}\right.$ & $\boldsymbol{\alpha}(-)$ & $\boldsymbol{\beta}(-)$ & $\boldsymbol{R}^{\mathbf{2}(-)}$ & AAE (\%) & ABE (\%) \\
\hline Gas-liquid & $0.098 \pm 0.002$ & 0.8 & 0.2 & 0.948 & 7.81 & -1 \\
Gas-liquid-solid & $0.351 \pm 0.008$ & 1.2 & -0.1 & 0.930 & 7.74 & -0.1 \\
\hline
\end{tabular}

${ }^{1} \varepsilon_{G T}(-), u_{S G R}(\mathrm{~m} / \mathrm{s}), C_{D}^{*}(-)$. 


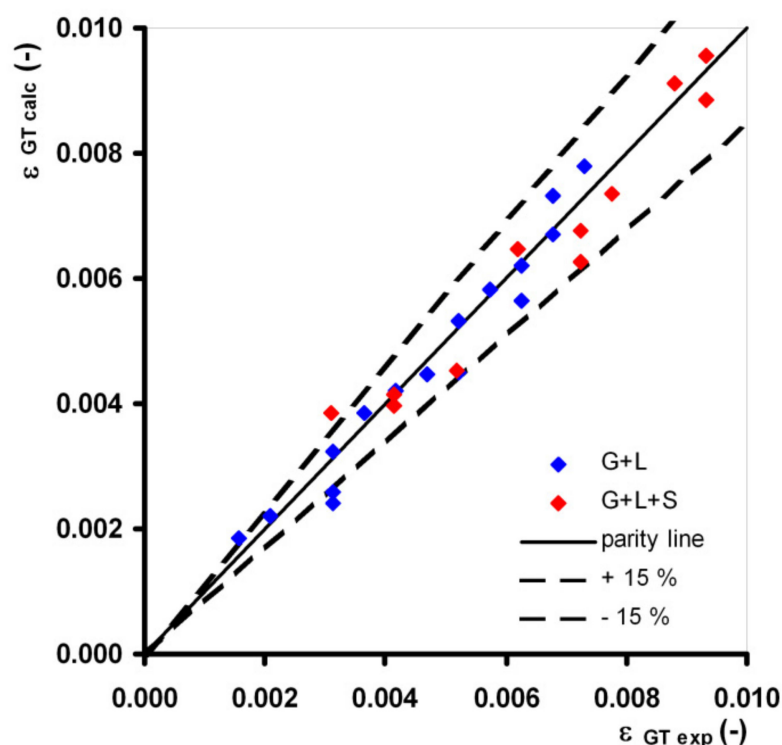

Figure 3. Total gas holdup $\alpha_{G T}$ : Comparison of experimental and calculated data using (4)—parity plot.

\subsection{Homogenization Time $\mathrm{t}_{\mathrm{H}}$}

The measured values of homogenization time are shown in Figure 4 as a function of dimensionless deflector clearance for the gas-liquid and gas-liquid-solid systems. For comparison, the values calculated using the proposed correlation (6) are shown also.

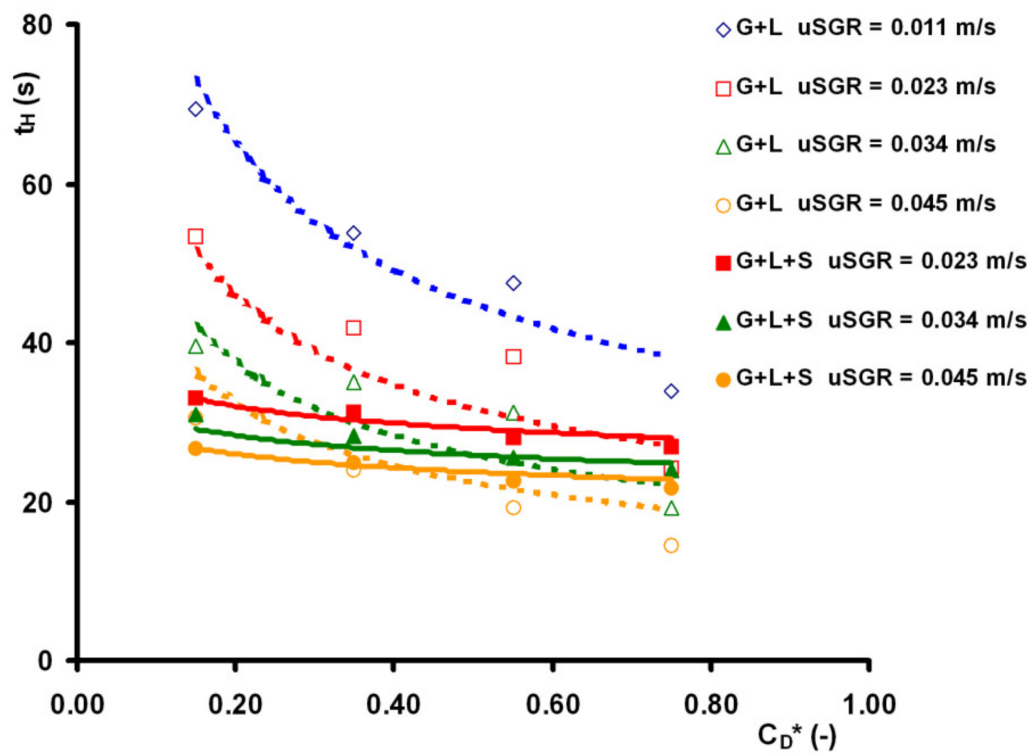

Figure 4. Homogenization time $t_{H}$ : Effect of dimensionless deflector clearance: Gas-liquid system (empty symbols), gas-liquid-solid system (full symbols), correlation (6) for gas-liquid system (dotted line), correlation (6) for gas-liquid-solid system (full line).

For gas-liquid system, reducing the deflector clearance, the homogenization time increases significantly. Homogenization time for $C_{D}^{*}=0.15$ is approx. two times higher compared to $C_{D}^{*}=0.75$. For lower $u_{S G R}$ and lower $C_{D}$, the presence of solid phase shortened the homogenization time. For the gas-liquid-solid system, the effect of deflector clearance is weaker compared to the gas-liquid system.

The values of the power law exponent for superficial gas velocity reported in the literature range usually in the range from -0.31 to -1.11 for the gas-liquid system. Analyzing 
overall data, the $\alpha$-values of -0.575 and -0.306 were obtained for the gas-liquid system and gas-liquid-solid system, respectively. The applicability of the $\alpha$-values of -0.5 and -0.3 for gas-liquid system and gas-liquid-solid system, respectively, was tested using the hypothesis test for each deflector clearance separately. The hypothesis test results are presented in Table 10. Except for $C_{D}^{*}=0.75$ in the gas-liquid-solid system, the proposed $\alpha$-values were statistically confirmed for both systems.

Furthermore, the independence of homogenization time of the deflector clearance was tested as the hypothesis, that is, $t_{H}=$ B. $\left(C_{D}^{*}\right)^{0}=$ const. (i.e., $\beta_{\text {pred }}=0$ ). The hypothesis test results are presented in Table 11. Statistically, the deflector clearance plays a role in the gas-liquid-solid system. Unlike this, the effect of deflector clearance can be neglected at lower $u_{S G R}$ in the gas-liquid system. However, the parity analysis shows that the deflector clearance should be taken into account. Analyzing the overall data, the $\beta$-values of -0.414 and -0.141 were obtained for the gas-liquid system and gas-liquid-solid system, respectively. For the data correlation, the $\beta$-values of -0.4 and -0.1 were assumed for the gas-liquid system and gas-liquid-solid system, respectively.

Table 10. Homogenization time $t_{H}$ : Results of the hypothesis testing for effect of riser superficial velocity $u_{S G R}$ for deflector clearance $C_{D}^{*}=$ const.

\begin{tabular}{|c|c|c|c|c|}
\hline & Gas-Liquid System & & $\begin{array}{l}\text { Gas-Liquid-Solid } \\
\text { System }\end{array}$ & \\
\hline Hypothesis Testing & $\begin{array}{c}\text { Relation: } \\
t_{H}=\mathrm{B}_{\mathrm{R}} \cdot\left(u_{S G R}\right)^{\alpha} \\
\alpha_{\text {calc }}(-)\end{array}$ & $\begin{array}{c}\text { Hypothesis }{ }^{1}: \\
t_{H}=\mathrm{B}_{\mathrm{H}} \cdot\left(u_{S G R}\right)^{0.8} \\
\mathrm{t}-\text { Characteristics } \\
|t|\end{array}$ & $\begin{array}{c}\text { Relation: } \\
t_{H}=\mathrm{B}_{\mathrm{R}} \cdot\left(u_{S G R}\right)^{\alpha} \\
\alpha_{\text {calc }}(-)\end{array}$ & $\begin{array}{c}\text { Hypothesis }{ }^{1}: \\
t_{H}=\mathrm{B}_{\mathrm{H}} \cdot\left(u_{S G R}\right)^{0.8} \\
\text { t-Characteristics } \\
|t|\end{array}$ \\
\hline$C_{D}^{*}=0.75$ & -0.595 & 1.4 (acceptable) & -0.306 & 16 (not acceptable) \\
\hline$C_{D}^{*}=0.55$ & -0.589 & 0.5 (acceptable) & -0.303 & 0.1 (acceptable) \\
\hline$C_{D}^{*}=0.35$ & -0.537 & 0.3 (acceptable) & -0.318 & 0.4 (acceptable) \\
\hline$C_{D}^{*}=0.15$ & -0.579 & 0.9 (acceptable) & -0.296 & 0.04 (acceptable) \\
\hline Overall data analysis & -0.575 & --- & -0.306 & --- \\
\hline
\end{tabular}

Table 11. Homogenization time $t_{H}$ : Results of the hypothesis testing for effect of deflector clearance $C_{D}$ on superficial gas velocity $u_{S G R}=$ const.

\begin{tabular}{|c|c|c|c|c|}
\hline & Gas-Liquid System & & $\begin{array}{l}\text { Gas-Liquid-Solid } \\
\text { System }\end{array}$ & \\
\hline Hypothesis Testing & $\begin{array}{c}\text { Relation: } \\
t_{H}=\mathrm{B}_{\mathrm{R}} \cdot\left(C_{D}^{*}\right)^{\beta} \\
\beta_{\text {calc }}(-)\end{array}$ & $\begin{array}{c}\text { Hypothesis }{ }^{1}: \\
t_{H}=\mathrm{B}_{\mathrm{H}} \cdot\left(C_{D}^{*}\right)^{0} \\
\mathrm{t}-\text { Characteristics } \\
|t|\end{array}$ & $\begin{array}{c}\text { Relation: } \\
t_{H}=\mathrm{B}_{\mathrm{R}} \cdot\left(C_{D}^{*}\right)^{\beta} \\
\beta_{\text {calc }}(-)\end{array}$ & $\begin{array}{c}\text { Hypothesis }{ }^{1}: \\
t_{H}=\mathrm{B}_{\mathrm{H}} \cdot\left(C_{D}^{*}\right)^{0} \\
\mathrm{t}-\text { Characteristics } \\
|t|\end{array}$ \\
\hline$u_{S G R}=0.011 \mathrm{~m} / \mathrm{s}$ & -0.404 & 4.2 (acceptable) & --- & --- \\
\hline$u_{S G R}=0.023 \mathrm{~m} / \mathrm{s}$ & -0.427 & 3 (acceptable) & -0.132 & 5.1 (not acceptable) \\
\hline$u_{S G R}=0.034 \mathrm{~m} / \mathrm{s}$ & -0.382 & 2.2 (acceptable) & -0.160 & 7.9 (not acceptable) \\
\hline$u_{S G R}=0.045 \mathrm{~m} / \mathrm{s}$ & -0.442 & 5.1 (not acceptable) & -0.132 & 6.6 (not acceptable) \\
\hline Overall data analysis & -0.414 & --- & -0.141 & --- \\
\hline
\end{tabular}

${ }^{1}$ Critical t-distribution $\mathrm{t}_{2,0.05}=4.3027$.

The evaluated parameters of the power-law correlation (6) and values of AAE, ABE, and $R^{2}$ are presented in Table 12 for the gas-liquid and gas-liquid-solid systems. The positive $\mathrm{ABE}$ value, higher compared to the $\mathrm{AAE}$ value, indicates an overall overestimation of the experimental homogenization time by the proposed correlation (6), especially for the gas-liquid system. The comparison of experimental data and the correlation given by 
Equation (6) is presented in Figure 5 for both systems. The lines representing $\pm 15 \%$ of the relative error are shown also in Figure 5 for illustration.

Table 12. Homogenization time $t_{H}$ : Evaluated parameters of correlation (6).

\begin{tabular}{lcccccc}
\hline \multicolumn{1}{c}{ System } & $\mathbf{C}^{\mathbf{1}}\left(\mathbf{s} \cdot(\mathbf{m} / \mathbf{s})^{-\boldsymbol{\alpha}}\right)$ & $\boldsymbol{\alpha}(-)$ & $\beta(-)$ & $\boldsymbol{R}^{\mathbf{2}}(-)$ & AAE (\%) & ABE (\%) \\
\hline Gas-liquid & $3.640 \pm 0.105$ & -0.5 & -0.4 & 0.91 & 13 & 2.72 \\
Gas-liquid-solid & $8.746 \pm 0.094$ & -0.3 & -0.1 & 0.917 & 3 & 0.44 \\
\hline
\end{tabular}

${ }^{1} t_{H}(\mathrm{~s}), u_{S G R}(\mathrm{~m} / \mathrm{s}), C_{D}^{*}(-)$.

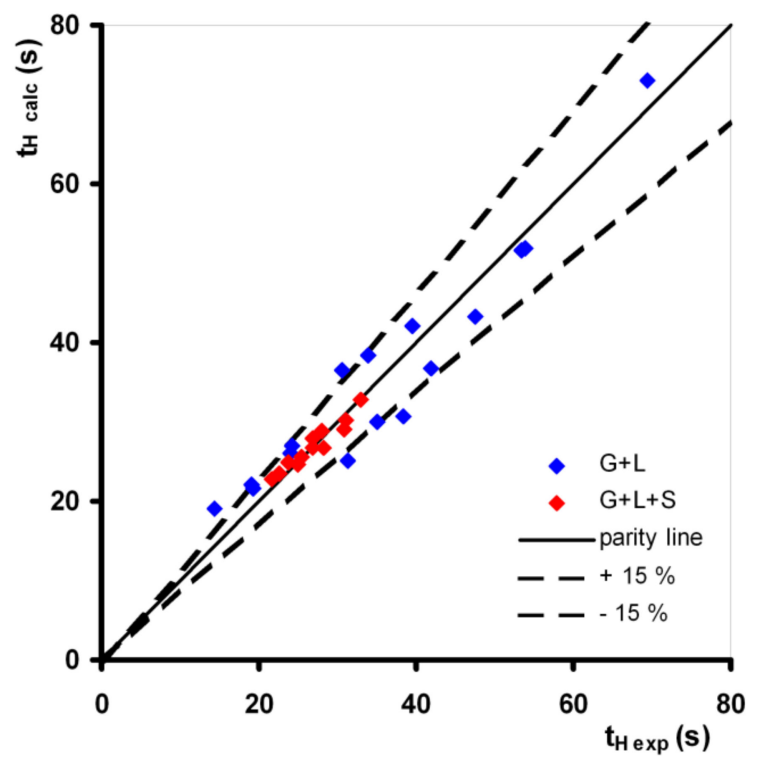

Figure 5. Homogenization time $t_{H}$ : Comparison of experimental and calculated data using (6)—parity plot.

Alternatively, the experimental data were successfully correlated using a combined exponential and power-law function (7). The evaluated parameters of the power-law correlation (7), and values of $\mathrm{AAE}, \mathrm{ABE}$, and $R^{2}$ are presented in Table 13 for the gasliquid and gas-liquid-solid system. The three times lower AAE value indicates better predictability of homogenization time by correlation (7) compared to correlation (6) for the gas-liquid system. The slightly positive ABE value indicates a practically uniform estimation of the homogenization time by the proposed correlation (7). The comparison of measured values and values calculated using the proposed correlation (7) is shown in Figure 6 as a function of the riser superficial gas velocity for the gas-liquid and gas-liquidsolid systems.

Table 13. Homogenization time $t_{H}$ : Evaluated parameters of correlation (7).

\begin{tabular}{lcccccc}
\hline \multicolumn{1}{c}{ System } & $\mathbf{C}^{\mathbf{1}}(\mathbf{s})$ & $\boldsymbol{\alpha}(\mathbf{s} / \mathbf{m})$ & $\boldsymbol{\beta}(-)$ & $\boldsymbol{R}^{\mathbf{2}}(-)$ & AAE (\%) & ABE (\%) \\
\hline Gas-liquid & $99.3 \pm 1.3$ & -24 & 0.6 & 0.981 & 4.13 & 0.1 \\
\hline Gas-liquid-solid & $41.8 \pm 0.4$ & -9 & 0.2 & 0.952 & 2.4 & 0.15 \\
\hline
\end{tabular}

${ }^{1} t_{H}(\mathrm{~s}), u_{S G R}(\mathrm{~m} / \mathrm{s}), C_{D}^{*}(-)$. 


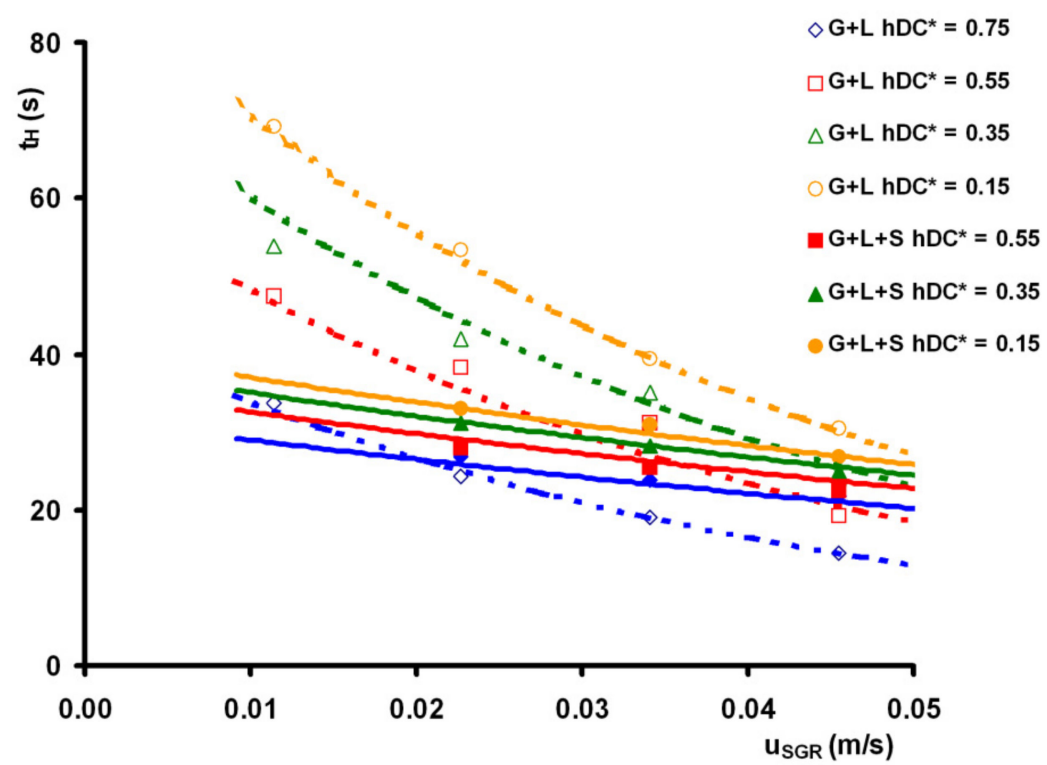

Figure 6. Homogenization time $t_{H}$ : Effect of riser superficial gas velocity: Gas-liquid system (empty symbols), gas-liquid-solid system (full symbols), correlation (7) for gas-liquid system (dotted line), correlation (7) for gas-liquid-solid system (full line).

The comparison of experimental data and the correlation given by Equation (7) is presented in Figure 7 for both systems. The lines representing the relative error of $\pm 15 \%$ are shown also in Figure 7 for illustration.

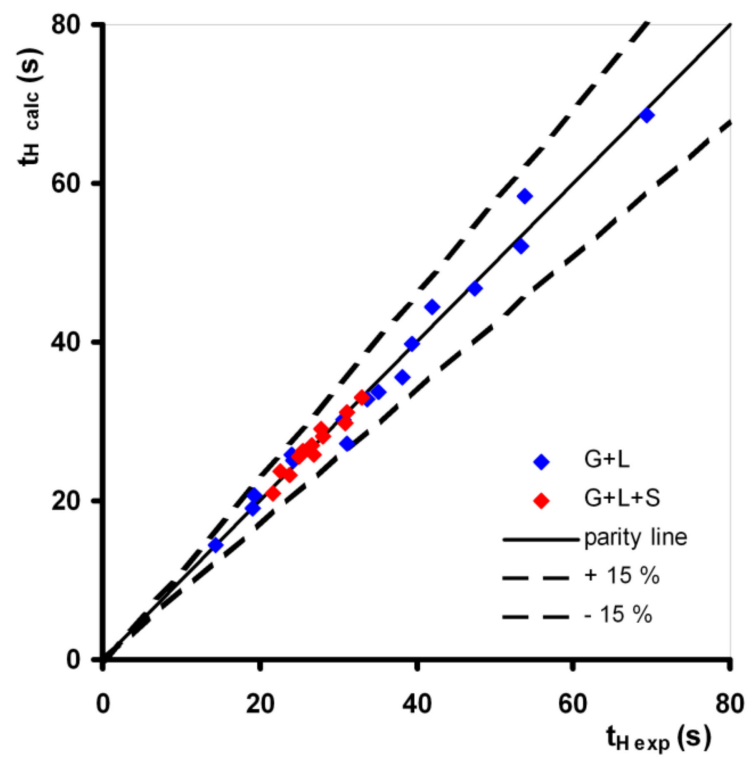

Figure 7. Homogenization time $t_{H}$ : Comparison of experimental and calculated data using (7)—parity plot.

\subsection{Overall Volumetric Liquid-Phase Mass Transfer Coefficient $k_{L} a$}

The values of the overall volumetric mass transfer coefficient corrected onto $20{ }^{\circ} \mathrm{C}$ are shown in Figure 8 as a function of dimensionless deflector clearance for the gas-liquid and gas-liquid-solid systems. For comparison, the values calculated using the proposed correlation (12) are shown also. 


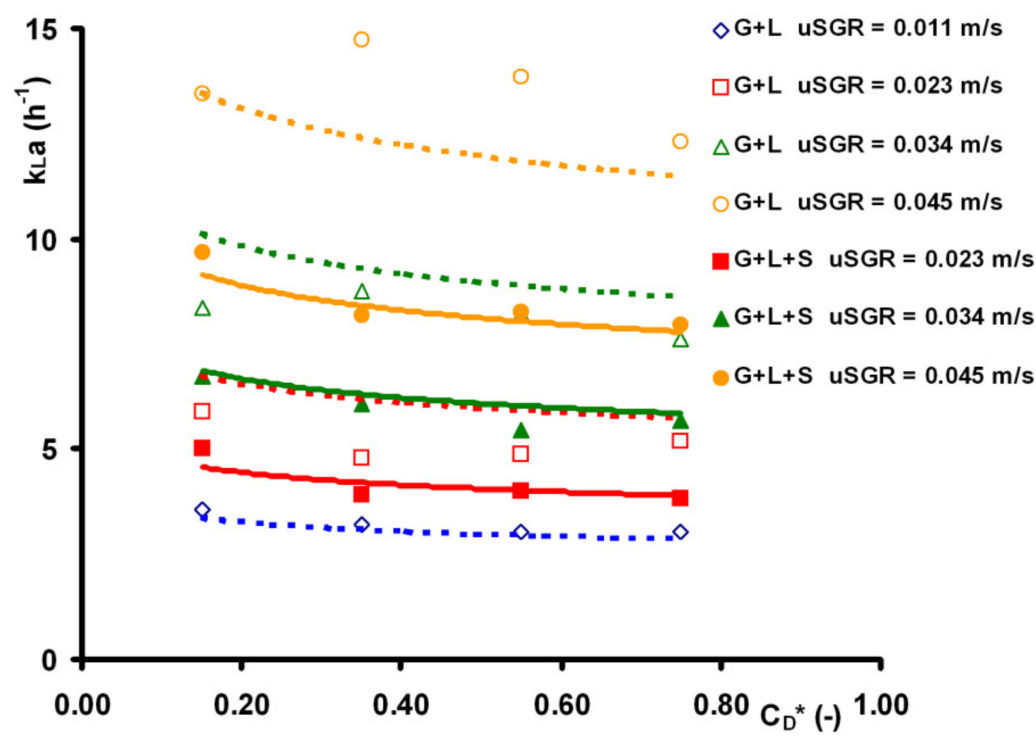

Figure 8. Overall volumetric mass transfer coefficient $k_{L} a$ : Effect of dimensionless deflector clearance: Gas-liquid system (empty symbols), gas-liquid-solid system (full symbols), correlation (12) for gas-liquid system (dotted line), correlation (12) for gas-liquid-solid system (full line).

For the gas-liquid system, reducing the deflector clearance, the overall volumetric mass transfer coefficient slightly increases. Mass transfer coefficient for $C_{D}^{*}=0.15$ is approx. $10-17 \%$ higher than for $C_{D}^{*}=0.75$. The presence of solid phase reduced the mass transfer coefficient by $15-35 \%$. In the gas-liquid-solid system, the effect of deflector clearance is more accentuated compared to the gas-liquid system. Mass transfer coefficient for $C_{D}^{*}=0.15$ is approx. $20-29 \%$ higher than for $C_{D}^{*}=0.75$.

The values of the power law exponent for superficial gas velocity reported in the literature range usually in the range from 0.642 to 1.12 for the gas-liquid system. Analyzing overall data, the $\alpha$-values of 1.009 and 1.019 were obtained for the gas-liquid system and gas-liquid-solid system, respectively. The applicability of the $\alpha$-values of 1 for the gas-liquid system and the gas-liquid-solid system was tested using a hypothesis test for each deflector clearance separately. The hypothesis test results are presented in Table 14. Except for $C_{D}^{*}=0.35$ in the gas-liquid-solid system, the proposed $\alpha$-value was statistically confirmed for both systems.

The independence of the overall volumetric mass transfer coefficient of the deflector clearance was tested as the hypothesis, that is, $k_{L} a=$ B. $\left(C_{D}^{*}\right) 0=$ const. (i.e., $\beta_{\text {pred }}=0$ ). The hypothesis test results are presented in Table 15. Statistically, the independence of deflector clearance was confirmed practically for all $u_{S G R}$ except the lowest $u_{S G R}$ of $0.011 \mathrm{~m} / \mathrm{s}$ in the gas-liquid system. However, the parity analysis shows that the deflector clearance should be taken into account for both systems. Analyzing the overall data, the $\beta$-values of -0.072 and -0.134 were obtained for the gas-liquid system and gas-liquid-solid system, respectively. For the data correlation, the $\beta$-value of -0.1 was assumed for the gas-liquid system and the gas-liquid-solid system. 
Table 14. Overall volumetric mass transfer coefficient $k_{L} a$ : Results of the hypothesis testing-effect of riser superficial velocity $u_{S G R}$ for deflector clearance $C_{D}^{*}=$ const.

\begin{tabular}{|c|c|c|c|c|}
\hline & Gas-Liquid System & & $\begin{array}{c}\text { Gas-Liquid-Solid } \\
\text { System }\end{array}$ & \\
\hline Hypothesis Testing & $\begin{array}{c}\text { Relation: } \\
k_{L} a=\mathrm{B}_{\mathrm{R}} \cdot\left(u_{S G R}\right)^{\alpha} \\
\alpha_{\text {calc }}(-)\end{array}$ & $\begin{array}{c}\text { Hypothesis }{ }^{1}: \\
k_{L} a=\mathrm{B}_{\mathrm{H}} \cdot\left(u_{S G R}\right)^{0.8} \\
\text { t-Characteristics } \\
|t|\end{array}$ & $\begin{array}{c}\text { Relation: } \\
k_{L} a=\mathrm{B}_{\mathrm{R}} \cdot\left(u_{S G R}\right)^{\alpha} \\
\alpha_{\text {calc }}(-)\end{array}$ & $\begin{array}{c}\text { Hypothesis }{ }^{1}: \\
k_{L} a=\mathrm{B}_{\mathrm{H}} \cdot\left(u_{S G R}\right)^{0.8} \\
\text { t-Characteristics } \\
|t|\end{array}$ \\
\hline$C_{D}^{*}=0.75$ & 0.973 & 0.2 (acceptable) & 1.045 & 0.7 (acceptable) \\
\hline$C_{D}^{*}=0.55$ & 1.069 & 0.4 (acceptable) & 1.027 & 0.1 (acceptable) \\
\hline$C_{D}^{*}=0.35$ & 1.075 & 0.4 (acceptable) & 1.064 & 4.4 (not acceptable) \\
\hline$C_{D}^{*}=0.15$ & 0.917 & 0.7 (acceptable) & 0.941 & 0.4 (acceptable) \\
\hline Overall data analysis & 1.009 & --- & 1.019 & --- \\
\hline
\end{tabular}

Table 15. Overall volumetric mass transfer coefficient $k_{L} a$ : Results of the hypothesis testing-effect of deflector clearance $C_{D}$ on superficial gas velocity $u_{S G R}=$ const.

\begin{tabular}{|c|c|c|c|c|}
\hline & Gas-Liquid System & & $\begin{array}{c}\text { Gas-Liquid-Solid } \\
\text { System }\end{array}$ & \\
\hline Hypothesis Testing & $\begin{array}{c}\text { Relation: } \\
k_{L} a=\mathrm{B}_{\mathrm{R}} \cdot\left(C_{D}^{*}\right)^{\beta} \\
\beta_{\text {calc }}(-)\end{array}$ & $\begin{array}{c}\text { Hypothesis }{ }^{1}: \\
k_{L} a=\mathrm{B}_{\mathrm{H}} \cdot\left(C_{D}^{*}\right)^{0} \\
\text { t-Characteristics } \\
|t|\end{array}$ & $\begin{array}{c}\text { Relation: } \\
k_{L} a=\mathrm{B}_{\mathrm{R}} \cdot\left(C_{D}^{*}\right)^{\beta} \\
\beta_{\text {calc }}(-)\end{array}$ & $\begin{array}{c}\text { Hypothesis }{ }^{1}: \\
k_{L} a=\mathrm{B}_{\mathrm{H}} \cdot\left(C_{D}^{*}\right)^{0} \\
\text { t-Characteristics } \\
|t|\end{array}$ \\
\hline$u_{S G R}=0.011 \mathrm{~m} / \mathrm{s}$ & -0.108 & 6.3 (not acceptable) & -- & -- \\
\hline$u_{S G R}=0.023 \mathrm{~m} / \mathrm{s}$ & -0.091 & 1.3 (acceptable) & -0.159 & 3.1 (acceptable) \\
\hline$u_{S G R}=0.034 \mathrm{~m} / \mathrm{s}$ & -0.049 & 1 (acceptable) & -0.125 & 4 (acceptable) \\
\hline$u_{S G R}=0.045 \mathrm{~m} / \mathrm{s}$ & -0.039 & 0.5 (acceptable) & -0.118 & 3.7 (acceptable) \\
\hline Overall data analysis & -0.072 & --- & -0.134 & --- \\
\hline
\end{tabular}

${ }^{1}$ Critical t-distribution $\mathrm{t}_{2,0.05}=4.3027$.

The evaluated parameters of the power-law correlation (12) and values of AAE, ABE, and $R^{2}$ are presented in Table 16 for the gas-liquid and gas-liquid-solid systems. The positive $\mathrm{ABE}$ value, higher compared to the $\mathrm{AAE}$ value, indicates an overall overestimation of the experimental $k_{L} a$ coefficient by the proposed correlation (12), especially for the gas-liquid system. The comparison of experimental data and the correlation given by Equation (12) is presented in Figure 9 for both systems. The lines representing the relative error of $\pm 15 \%$ are shown also in Figure 9 for illustration.

Table 16. Overall volumetric mass transfer coefficient $k_{L} a$ : Evaluated parameters of correlation (12).

\begin{tabular}{|c|c|c|c|c|c|c|}
\hline System & $\begin{array}{c}C^{1} \\
\left(h^{-1} \cdot(m / s)^{-\alpha}\right)\end{array}$ & $\alpha(-)$ & $\beta(-)$ & $R^{2}(-)$ & AAE (\%) & $\operatorname{ABE}(\%)$ \\
\hline Gas-liquid & $246 \pm 8.3$ & 1 & -0.1 & 0.923 & 11.2 & 4.7 \\
\hline Gas-liquid-solid & $166.6 \pm 2.4$ & 1 & -0.1 & 0.974 & 4.14 & 1 \\
\hline
\end{tabular}




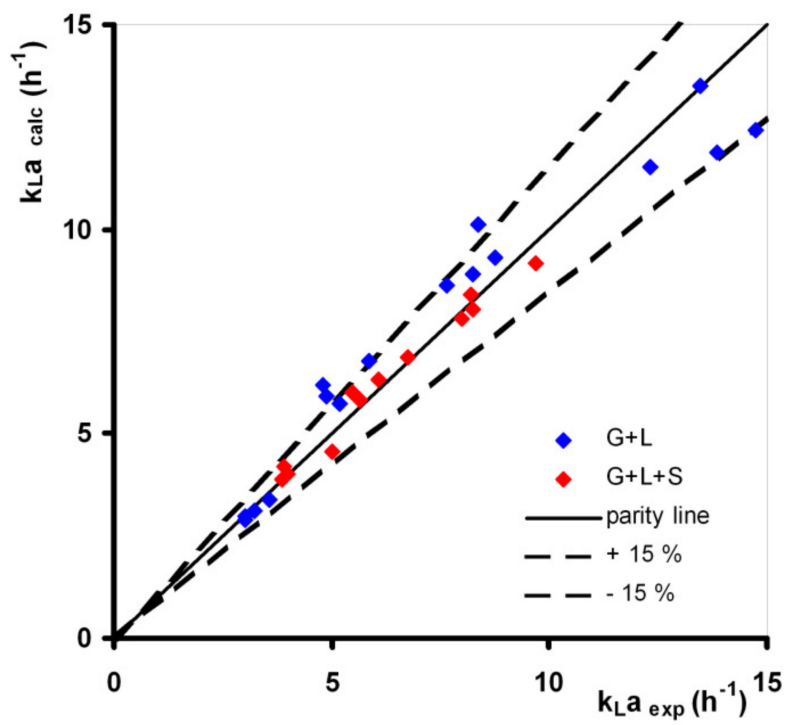

Figure 9. Overall volumetric mass transfer coefficient $k_{L} a$ : Comparison of experimental and calculated data using (12)-parity plot.

Alternatively, the experimental data were successfully correlated using a combined exponential and power-law function (13). The evaluated parameters of the power-law correlation (13) and values of $\mathrm{AAE}, \mathrm{ABE}$, and $R^{2}$ are presented in Table 17 for the gas-liquid and gas-liquid-solid system. The approx. three times lower AAE value indicates better predictability of $k_{L} a$ coefficient by correlation (13) compared to correlation (12) for the gasliquid system. The slightly positive $\mathrm{ABE}$ value indicates a practically uniform estimation of the $k_{L} a$ coefficient by the proposed correlation (13).

Table 17. Overall volumetric mass transfer coefficient $k_{L} a$ : Evaluated parameters of correlation (13).

\begin{tabular}{lcccccc}
\hline \multicolumn{1}{c}{ System } & $\mathbf{C}^{\mathbf{1}}\left(\mathbf{h}^{-\mathbf{1}}\right)$ & $\alpha(\mathbf{s} / \mathbf{m})$ & $\boldsymbol{\beta}(-)$ & $\boldsymbol{R}^{\mathbf{2}}(-)$ & AAE (\%) & ABE (\%) \\
\hline Gas-liquid & $1.81 \pm 0.03$ & 42 & -0.1 & 0.979 & 4.5 & 0.4 \\
\hline Gas-liquid-solid & $1.89 \pm 0.02$ & 31 & -0.1 & 0.984 & 3.2 & 0.6 \\
\hline
\end{tabular}

${ }^{1} k_{L} a\left(\mathrm{~h}^{-1}\right), u_{S G R}(\mathrm{~m} / \mathrm{s}), C_{D}^{*}(-)$.

The comparison of measured values and values calculated using the proposed correlation (13) is shown in Figure 10 as a function of the riser superficial gas velocity for the gas-liquid and gas-liquid-solid systems. The comparison of experimental data and the correlation given by Equation (13) is presented in Figure 11 for both systems. The lines representing $\pm 15 \%$ of the relative error are shown also in Figure 11 for illustration 


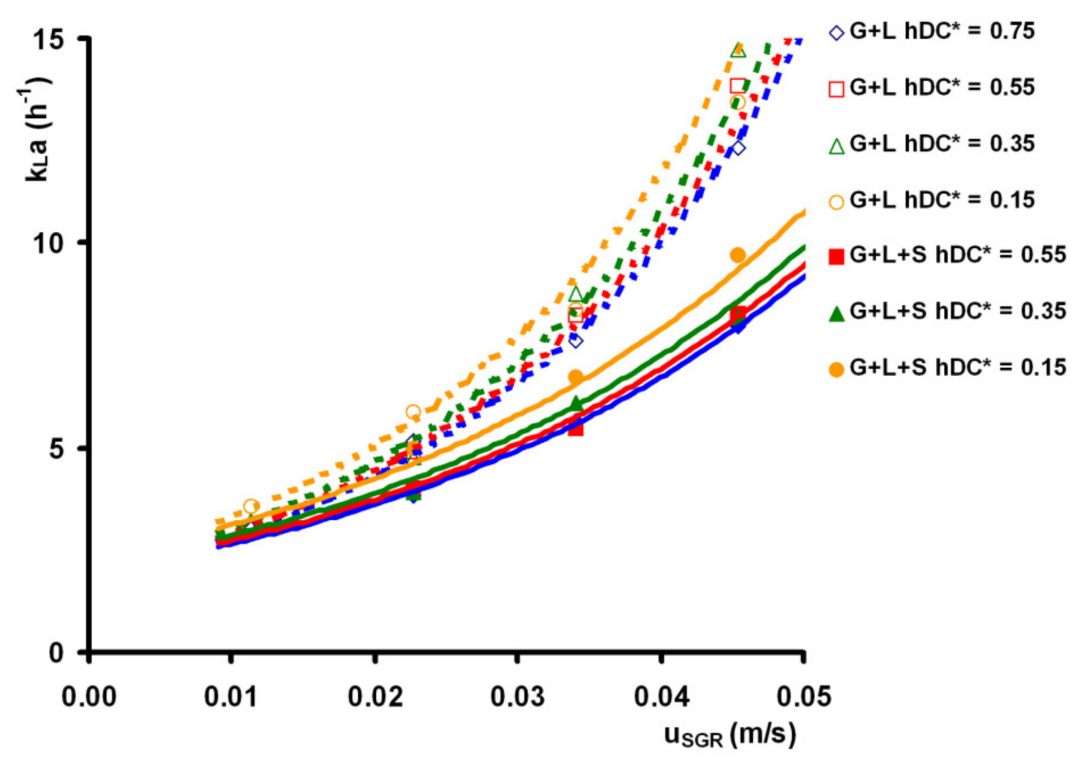

Figure 10. Overall volumetric mass transfer coefficient $k_{L} a$ : Effect of riser superficial gas velocity: Gas-liquid system (empty symbols), gas-liquid-solid system (full symbols), correlation (13) for gas-liquid system (dotted line), correlation (13) for gas-liquid-solid system (full line).

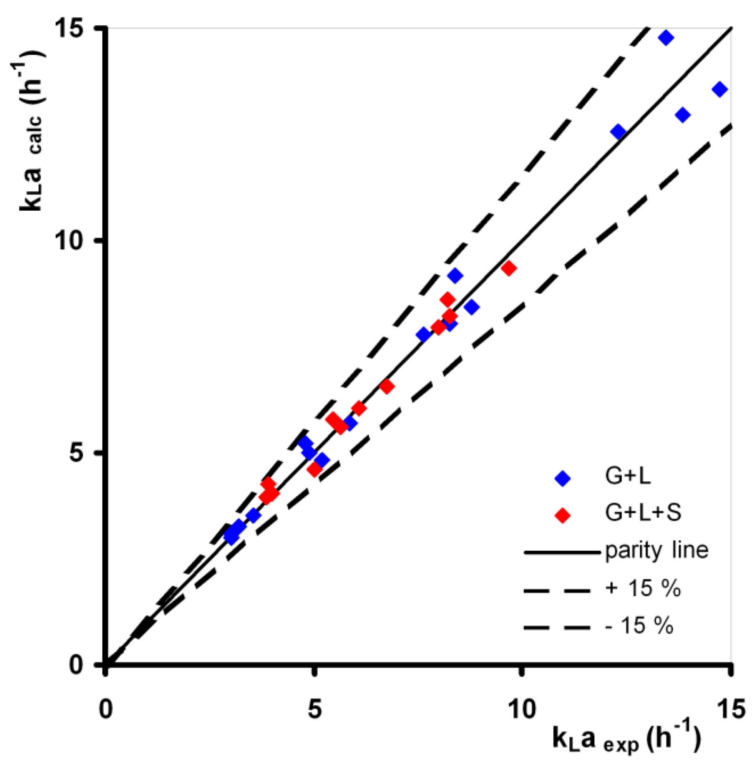

Figure 11. Overall volumetric mass transfer coefficient $k_{L} a$ : Comparison of experimental and calculated data using (13)—parity plot.

\section{Conclusions}

The experiments were carried out in a laboratory conical jet-loop airlift bioreactor of $300 \mathrm{~mm}$ in inner diameter and volume of $62.5 \mathrm{dm}^{3}$. As a novelty, the gas separator was equipped with an adjustable deflector placed above the riser compared with a standard design. The effects of riser superficial gas velocity $u_{S G R}$ on total gas holdup $\varepsilon_{G T}$, homogenization time $t_{H}$, and overall volumetric liquid-phase mass transfer coefficient $k_{L} a$ were investigated in the two-phase air-water system and three-phase air-water-PVC particle system with the volumetric solid fraction of $1 \%$. The airlift was operated in regime I according to the classification given by Heijnen et al. [27]. The experimental data were successfully correlated using a power-law function or using a combined exponential- and power-law function. The evaluated values of the power law exponent for superficial gas 
velocity were compared with the values reported in the literature for the gas-liquid system using the hypothesis testing method.

The following results were gained:

- Reducing the deflector clearance, the total gas holdup decreases for the gas-liquid system. Unlike this, the weak effect of deflector clearance was observed for the gas-liquid-solid system, especially for higher values of riser superficial gas velocity;

- For the gas-liquid system, when reducing deflector clearance, homogenization time increased twice compared to the highest deflector clearance tested. For the gas-liquidsolid system, the effect of deflector clearance is weaker compared to the gas-liquid system and the presence of solid phase shortens the homogenization time, especially for lower riser superficial gas velocity and deflector clearance;

- For the gas-liquid system, when reducing the deflector clearance, the overall volumetric mass transfer coefficient slightly increases by $10-17 \%$. The presence of solid phase reduced the mass transfer coefficient by $15-35 \%$. In the gas-liquid-solid system, the effect of deflector clearance is more accentuated compared to the gas-liquid system. The mass transfer coefficient for the lowest tested deflector clearance was approx. 20-29\% higher than for the highest tested deflector clearance.

- The airlift reactors equipped with internals placed in the gas separation section may be a promising novel airlift reactor design, as reported by Zhang et al. [30].

The future research will be focused on the overall gas-to-liquid heat transfer investigation.

Author Contributions: Methodology, R.Š. and J.D.; validation, J.D. and R.̌̌.; investigation, J.D.; data curation, J.D. and R.Š.; writing — original draft preparation, review and editing, R.Š.; visualization, R.S.; supervision, R.Š. Both authors have read and agreed to the published version of the manuscript.

Funding: This research and the APC were funded and supported by the MINISTRY OF EDUCATION, YOUTH AND SPORTS OF THE CZECH REPUBLIC, grant number OP RDE CZ.02.1.01/0.0/0.0/16_019/ 0000753 Research centre for low-carbon energy technologies.

Conflicts of Interest: The authors declare no conflict of interest.

\section{Nomenclature}

\begin{tabular}{|c|c|c|}
\hline AAE & average absolute error & $\%$ \\
\hline $\mathrm{ABE}$ & average bias error & $\%$ \\
\hline$A_{C}$ & column cross-section area & $\mathrm{m}^{2}$ \\
\hline$A_{D}$ & downcomer cross-section area & $\mathrm{m}^{2}$ \\
\hline$A_{R}$ & riser cross-section area & $\mathrm{m}^{2}$ \\
\hline Bo & Bond number; $\mathrm{Bo}=\mathrm{g} \cdot \rho_{\mathrm{L}} \cdot \mathrm{D}_{\mathrm{char}}{ }^{2} / \sigma$ & - \\
\hline $\mathrm{B}_{\mathrm{R}}$ & bottom spatial ratio; $\mathrm{B}=\mathrm{C}_{\mathrm{RB}} / \mathrm{D}_{\mathrm{R}}$ & - \\
\hline$c_{L}$ & mass concentration of liquid dissolved oxygen & $\mathrm{kg} / \mathrm{m}^{3}$ \\
\hline$c_{L}^{*}$ & mass concentration of dissolved oxygen in liquid at saturation & $\mathrm{kg} / \mathrm{m}^{3}$ \\
\hline $\mathrm{C}$ & temperature correction factor in Equation (11) & - \\
\hline $\mathrm{C}$ & constant of proportionality in Equation (4) & $(\mathrm{m} / \mathrm{s})^{-\alpha}$ \\
\hline $\mathrm{C}$ & constant of proportionality in Equation (6) & $\mathrm{s} \cdot(\mathrm{m} / \mathrm{s})^{-\alpha}$ \\
\hline $\mathrm{C}$ & constant of proportionality in Equation (7) & $\mathrm{s}$ \\
\hline $\mathrm{C}$ & constant of proportionality in Equation (12) & $\mathrm{h}^{-1} \cdot(\mathrm{m} / \mathrm{s})^{-\alpha}$ \\
\hline $\mathrm{C}$ & constant of proportionality in Equation (13) & $\mathrm{h}^{-1}$ \\
\hline$C_{D}$ & deflector clearance & $\mathrm{m}$ \\
\hline $\mathrm{C}_{\mathrm{RB}}$ & riser bottom clearance & $\mathrm{m}$ \\
\hline $\mathrm{C}_{\mathrm{RU}}$ & riser upper clearance & $\mathrm{m}$ \\
\hline$d_{h}$ & hole diameter (in gas distributor) & $\mathrm{m}$ \\
\hline $\mathrm{D}_{\mathrm{C}}$ & column inner diameter & $\mathrm{m}$ \\
\hline
\end{tabular}




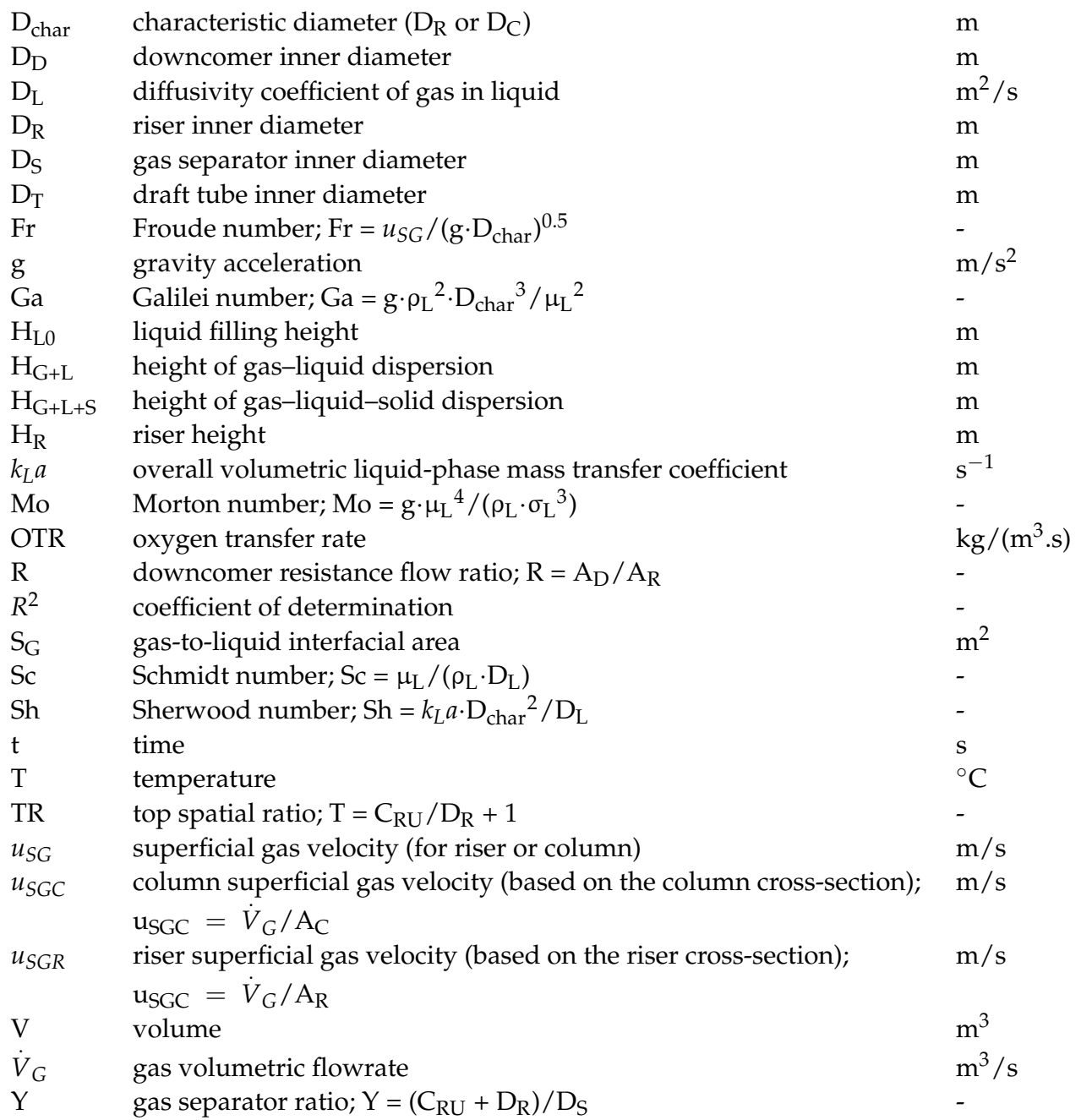

\section{Greek Letters}

$\begin{array}{lll}\alpha & \text { power-law exponent in Equations (4), (6), and (12) } & - \\ \alpha & \text { power-law exponent in Equations (7) and (13) } & \mathrm{s} / \mathrm{m} \\ \alpha & \text { significance level } & - \\ \beta & \text { power-law exponent in Equations (4), (6), (7), (12), and (13) } & - \\ \varepsilon & \text { gas hold up } & - \\ \varphi_{\mathrm{S}} & \text { volumetric solid fraction } & - \\ \mu_{\mathrm{L}} & \text { dynamic viscosity of liquid } & \mathrm{Pa} . \mathrm{s} \\ v & \text { kinematic viscosity } & \mathrm{m}^{2} / \mathrm{s} \\ \rho & \text { density } & \mathrm{kg} / \mathrm{m}^{3} \\ \sigma & \text { surface tension } & \mathrm{N} / \mathrm{m}^{2} \\ \tau & \text { response time of oxygen probe } & \mathrm{S}\end{array}$




\begin{tabular}{ll}
\multicolumn{2}{l}{ Indexes } \\
B & bottom \\
$\mathrm{C}$ & column \\
calc & calculated \\
$\mathrm{D}$ & downcomer \\
$\mathrm{G}$ & gas phase \\
$\mathrm{L}$ & liquid phase \\
pred & predicted \\
$\mathrm{R}$ & riser \\
$\mathrm{S}$ & gas separator \\
$\mathrm{S}$ & solid phase \\
$\mathrm{T}$ & draft tube \\
$\mathrm{T}$ & total \\
$\mathrm{U}$ & upper
\end{tabular}

\section{Abbreviation}

ALR airlift reactor

\section{References}

1. Lafarga, T.; Acién-Fernández, F.G.; Garcia-Vaquero, M. Bioactive peptides and carbohydrates from seaweed for food applications: Natural occurrence, isolation, purification, and identification. Algal Res. 2020, 48, 101909. [CrossRef]

2. Papacek, S.; Petera, K.; Masaló, I.; Oca, J. Modeling and optimization of flow pattern in tanks for seaweed culture. In Proceedings of the Aquaculture Europe 2017: Cooperation for Growth-Abstracts EA2017, Dubrovnik, Croatia, 7-20 October 2017; European Aquaculture Society: Oostende, Belgium, 2017; p. 874.

3. Dolganyuk, V.; Belova, D.; Babich, D.; Prosekov, A.; Ivanova, S.; Katserov, D.; Patyukov, N.; Sukhikh, S. Microalgae: A Promising Source of Valuable Bioproducts. Biomolecules 2020, 10, 1153. [CrossRef] [PubMed]

4. Guedes, A.C.; Amaro, H.M.; Malcata, F.X. Microalgae as Sources of Carotenoids. Mar. Drugs 2011, 9, 625-644. [CrossRef] [PubMed]

5. Ranjbar, R.; Inoue, R.; Katsuda, T.; Yamaji, H.; Katoh, S. High efficiency production of astaxanthin in an airlift photobioreactor. J. Biosci. Bioeng. 2008, 106, 204-207. [CrossRef]

6. Lakshmidevi, R.; Gandhi, N.N.; Muthukumar, K. Enhanced biomass and lutein production by mixotrophic cultivation of Scenedesmus sp. using crude glycerol in airlift photobioreactor. Biochem. Eng. J. 2020, 161, 107684. [CrossRef]

7. Lage, S.; Gojkovic, Z.; Funk, C.; Gentili, F.G. Algal Biomass from wastewater and flue gases as a source of bioenergy. Energies 2018, 11, 664. [CrossRef]

8. Zhang, X. Microalgae Removal of $\mathrm{CO}_{2}$ from Flue Gas; IEA Clean Coal Centre: London, UK, 2015; ISBN 9789290295723.

9. Arroyo, C.A.; Contreras, J.L.; Zeifert, B.; Ramírez, C.C. $\mathrm{CO}_{2}$ capture of the gas emission using a catalytic converter and airlift bioreactors with the microalga Scenedesmus dimorphus. Appl. Sci. 2019, 9, 3212. [CrossRef]

10. Saad, M.G.; Dosoky, N.S.; Zoromba, M.S.; Shafik, H.M. Algal Biofuels: Current Status and Key Challenges. Energies 2019, $12,1920$. [CrossRef]

11. Hosseini, N.S.; Shang, H.; Ross, G.M.; Scott, J.A. Comparative analysis of top-lit bubble column and gas-lift bioreactors for microalgae-sourced biodiesel production. Energy Convers. Manag. 2016, 130, 230-239. [CrossRef]

12. SundaRajan, P.; Gopinath, K.P.; Greetham, D.; Antonysamy, A.J. A review on cleaner production of biofuel feedstock from integrated $\mathrm{CO}_{2}$ sequestration and wastewater treatment system. J. Clean. Prod. 2019, 210, 445-458. [CrossRef]

13. Hosseini, N.S.; Shang, H.; Ross, G.M.; Scott, J.A. Microalgae cultivation in a novel top-lit gas-lift open bioreactor. Bioresour. Technol. 2015, 192, 432-440. [CrossRef]

14. Alami, A.H.; Alasad, S.; Ali, M.; Alshamsi, M. Investigating algae for $\mathrm{CO}_{2}$ capture and accumulation and simultaneous production of biomass for biodiesel production. Sci. Total Environ. 2021, 759, 143529. [CrossRef] [PubMed]

15. Ugwu, C.U.; Aoyagi, H.; Uchiyama, H. Photobioreactors for mass cultivation of algae. Bioresour. Technol. 2008, 99, 4021-4028. [CrossRef] [PubMed]

16. Singh, R.N.; Sharma, S. Development of suitable photobioreactor for algae production-A review. Renew. Sustain. Energy Rev. 2012, 16, 2347-2353. [CrossRef]

17. Chew, K.W.; Chia, S.R.; Show, P.L.; Yap, Y.J.; Ling, T.C.; Chang, J.-S. Effects of water culture medium, cultivation systems and growth modes for microalgae cultivation: A review. J. Taiwan Inst. Chem. Eng. 2018, 91, 332-344. [CrossRef]

18. Assunção, J.; Malcata, F.X. Enclosed “non-conventional” photobioreactors for microalga production: A review. Algal Res. 2020, 52, 102107. [CrossRef] 
19. Žižka, M.; Šulc, R.; Ditl, P. Heat transfer between gas and liquid in a bubble column. Chem. Eng. Trans. 2017, 57, 1261-1266. [CrossRef]

20. Žižka, M.; Šulc, R.; Ditl, P. Heat transfer between gas and non-coalescent liquid in a bubble column. Chem. Eng. Trans. 2019, 74, 1057-1062. [CrossRef]

21. Zhang, T.; Wei, C.; Feng, C.; Ren, Y.; Wu, H.; Preis, S. Advances in characteristics analysis, measurement methods and modeling of flow dynamics in airlift reactors. Chem. Eng. Process. Process Intensif. 2019, 144, 107633. [CrossRef]

22. Kaewpintong, K.; Shotipruk, A.; Powtongsook, S.; Pavasant, P. Photoautotrophic high-density cultivation of vegetative cells of Haematococcus pluvialis in airlift bioreactor. Bioresour. Technol. 2007, 98, 288-295. [CrossRef]

23. Chiu, S.-Y.; Tsai, M.-T.; Kao, C.-Y.; Ong, S.-C.; Lin, C.-S. The airlift photobioreactors with flow patterning for high-density cultures of microalgae and carbon dioxide removal. Eng. Life Sci. 2009, 9, 254-260. [CrossRef]

24. Hladíková, M.; Šulc, R. Selection of a separation method used for harvesting of microalgae from aqueous solution. Chem. Eng. Trans. 2021, 86, 157-162. [CrossRef]

25. Belohlav, V.; Jirout, T. Design methodology of industrial equipment for microalgae biomass primary harvesting and dewatering Chem. Eng. Trans. 2019, 76, 919-924. [CrossRef]

26. Acién, F.G.; Fernández, J.M.; Magán, J.J.; Molina, E. Production cost of a real microalgae production plant and strategies to reduce it. Biotechnol. Adv. 2012, 30, 1344-1353. [CrossRef] [PubMed]

27. Heijnen, J.J.; Hols, J.; van der Lans, R.G.J.M.; van Leeuwen, H.L.J.M.; Mulder, A.; Weltevrede, R. A simple hydrodynamic model for the liquid circulation velocity in a full-scale two- and three-phase internal airlift reactor operating in the gas recirculation regime. Chem. Eng. Sci. 1997, 52, 2527-2540. [CrossRef]

28. Koide, K.; Kimura, M.; Nitta, H.; Kawabata, H. Liquid circulation in bubble column with draught tube. J. Chem. Eng. Jpn. 1988, 21, 393-399. [CrossRef]

29. Lu, X.P.; Ding, J.; Wang, Y.R.; Shi, J. Comparison of the hydrodynamics and mass transfer characteristics of a modified square airlift reactor with common airlift reactors. Chem. Eng. Sci. 2000, 55, 2257-2263. [CrossRef]

30. Zhang, T.; Wei, C.; Feng, C.; Zhu, J. A novel airlift reactor enhanced by funnel internals and hydrodynamics prediction by the CFD method. Bioresour. Technol. 2012, 104, 600-607. [CrossRef]

31. Chisti, M.Y. Airlift Bioreactors; Elsevier: London, UK, 1989; ISBN 1851663207.

32. Juraščík, M.; Blažej, M.; Annus, J.; Markoš, J. Experimental measurements of volumetric mass transfer coefficient by the dynamic pressure-step method in internal loop airlift reactors of different scale. Chem. Eng. J. 2006, 125, 81-87. [CrossRef]

33. Albijanić, B.; Havran, V.; Petrović, D.L.; Durić, M.; Tekić, M.N. Hydrodynamics and mass transfer in a draft tube airlift reactor with dilute alcohol solutions. AIChE J. 2007, 53, 2897-2904. [CrossRef]

34. Gavrilescu, M.; Tudose, R.Z. Concentric-tube airlift bioreactors. Part I: Effects of geometry on gas holdup. Bioprocess Eng. 1998, 19, 37-44. [CrossRef]

35. Gouveia, E.R.; Hokka, C.O.; Badino, A.C. The effects of geometry and operational conditions on gas holdup, liquid circulation and mass transfer in an airlift reactor. Braz. J. Chem. Eng. 2003, 20, 363-374. [CrossRef]

36. Miron, A.S.; Camacho, F.G.; Gomez, A.C.; Grima, E.M.; Chisti, Y. Bubble-column and airlift photobioreactors for algal culture. AIChE J. 2000, 46, 1872-1887. [CrossRef]

37. Bando, Y.; Hayakawa, H.; Nishimura, M. Effects of the equipment dimensions on liquid mixing time of bubble column with draft tube. J. Chem. Eng. Jpn. 1998, 28, 225-227. [CrossRef]

38. Gavrilescu, M.; Tudose, R.Z. Modeling mixing parameters in concentric-tube airlift bioreactors. Part I: Mixing time. Bioprocess Eng. 1999, 20, 423-428. [CrossRef]

39. Petrović, D.L.; Pošarac, D.; Duduković, A. Prediction of mixing time in airlift reactors. Chem. Eng. Commun. 1995, 133, 1-9. [CrossRef]

40. Koide, K.; Kurematsu, K.; Iwamoto, S.; Iwata, Y.; Horibe, K. Gas holdup and volumetric liquid-phase mass-transfer coefficient in bubble column with draught tube and with gas dispersion into tube. J. Chem. Eng. Jpn. 1983, 16, 413-419. [CrossRef]

41. Gavrilescu, M.; Tudose, R.Z. Concentric-tube airlift bioreactors. Part III: Effects of geometry on mass transfer. Bioprocess Eng. 1998, 19, 175-178. [CrossRef]

42. Cerri, M.O.; Badino, A.C. Oxygen transfer in three scales of concentric tube airlift bioreactors. Biochem. Eng. J. 2010, 51, 40-47. [CrossRef]

43. Akita, K.; Yoshida, F. Gas holdup and volumetric mass-transfer coefficient in bubble columns-Effects of liquid properties. Ind. Eng. Chem. Process Des. Dev. 1973, 12, 76-80. [CrossRef]

44. Luo, L.; Liu, F.; Xu, Y.; Yuan, J. Hydrodynamics and mass transfer characteristics in an internal loop airlift reactor with different spargers. Chem. Eng. J. 2011, 175, 494-504. [CrossRef]

45. Koide, K.; Shibata, K.; Ito, H.; Kim, S.Y.; Ohtaguchi, K. Gas holdup and volumetric liquid-phase mass-transfer coefficient in a gel-particle suspended bubble column with draught tube. J. Chem. Eng. Jpn. 1992, 25, 11-16. [CrossRef]

46. Yang, T.; Geng, S.; Yang, C.; Huang, Q. Hydrodynamics and mass transfer in an internal airlift slurry reactor for process intensification. Chem. Eng. Sci. 2018, 184, 126-133. [CrossRef]

47. Sastaravet, P.; Bun, S.; Wongwailikhit, K.; Chawaloesphonsiya, N.; Fujii, M.; Painmanakul, P. Relative effect of additional solid media on bubble hydrodynamics in bubble column and airlift reactors towards mass transfer enhancement. Processes $2020,8,713$. [CrossRef] 
48. Šulc, R.; Dymák, J. Hydrodynamics and mass transfer in conical internal jet-loop airlift bioreactor equipped with a deflector. In Proceedings of the 26th European Biomass Conference and Exhibition, Copenhagen, Denmark, 14-17 May 2018; ETA-Florence Renewable Energies: Florence, Italy, 2018. ISBN 9788889407189. [CrossRef]

49. Kabátek, J.; Ditl, P.; Novák, V. Helax-A new type of static mixer-Operation characteristics and comparison with other types. Chem. Eng. Process. 1989, 25, 59-64. [CrossRef]

50. Merchuk, J.C.; Yona, S.; Siegel, M.H.; Zvi, A.B. On the First-order approximation to the response of dissolved oxygen electrodes for dynamic $k_{L} a$ estimation. Biotechnol. Bioeng. 1990, 35, 1161-1163. [CrossRef]

51. Sardeing, R.; Aubin, J.; Xuereb, C. Gas-liquid Mass Transfer: A comparison of down- and up-pumping axial flow impellers with radial turbines. Chem. Eng. Res. Des. 2004, 82, 1589-1596. [CrossRef]

52. Bewtra, J.K.; Nicholas, W.R.; Polkowski, L.B. Effect of temperature on oxygen transfer in water. Water Res. 1970, 4, 115-123. [CrossRef]

53. Nogaj, R.J.; Hurwitz, E. Determination of aerator efficiency under process conditions. In Proceedings of the Engineering Bulletin of Purdue University, 18th Industrial Waste Conference, West Lafayette, IL, USA, 30 April-2 May 1963; Purdue Univ.: West Lafayette, IL, USA, 1963; pp. 674-684.

54. Lee, J. Development of a model to determine mass transfer coefficient and oxygen solubility in bioreactors. Heliyon 2017, 3 , e00248. [CrossRef]

55. Bowerman, B.L.; O'Connell, R.T. Applied Statistics: Improving Business Processes; Richard D. Irwin: Homewood, IL, USA, 1997; ISBN 025619386X.

56. Qian, X. Statistical Analysis and Evaluation of the Advanced Biomass and Natural Gas Co-Combustion Performance. Ph.D. Thesis, Morgan State University, Baltimore, MD, USA, May 2019.

57. Qian, X.; Lee, S.; Soto, A.-M.; Chen, G. Regression Model to Predict the Higher Heating Value of Poultry Waste from Proximate Analysis. Resources 2018, 7, 39. [CrossRef]

58. Eboh, F.C.; Ahlström, P.; Richards, T. Estimating the specific chemical exergy of municipal solid waste. Energy Sci. Eng. 2016, 4, 217-231. [CrossRef] 